\title{
The proinflammatory response induced by the Cytolethal Distending Toxin depends on cGAS
}

Benoît J. Pons

INRA UMR 1331: Toxicologie Alimentaire

\section{Aurélie Pettes-Duler}

INRA UMR 1331: Toxicologie Alimentaire

Claire Naylies

INRA UMR 1331: Toxicologie Alimentaire

\section{Frédéric Taieb}

Institut de Recherche en Santé Digestive

\section{Catherine Bouchenot}

INRA UMR 1331: Toxicologie Alimentaire

\section{Saleha Hashim}

INRA UMR 1331: Toxicologie Alimentaire

\section{Soraya Tadrist}

INRA UMR 1331: Toxicologie Alimentaire

\section{Yannick Lippi}

INRA UMR 1331: Toxicologie Alimentaire

\section{Gladys Mirey}

INRA UMR 1331: Toxicologie Alimentaire

Julien Vignard ( $\sim$ julien.vignard@toulouse.inra.fr)

INRA UMR 1331: Toxicologie Alimentaire https://orcid.org/0000-0001-6379-1741

\section{Research Article}

Keywords: cGAS, Cytolethal Distending Toxin, DNA Damage Response, Proinflammatory response, Micronucleus, Mitosis

Posted Date: February 16th, 2021

DOl: https://doi.org/10.21203/rs.3.rs-162979/v1

License: (9) (1) This work is licensed under a Creative Commons Attribution 4.0 International License. Read Full License 
Version of Record: A version of this preprint was published at Cellular and Molecular Life Sciences on July 25th, 2021. See the published version at https://doi.org/10.1007/s00018-021-03902-x. 


\section{Abstract}

The Cytolethal Distending Toxin (CDT) is a bacterial genotoxin produced by pathogenic bacteria causing major foodborne diseases worldwide. CDT activates the DNA damage response and induces inflammatory signatures in host cells, but the precise relationship between these outcomes has not been addressed so far. Here, we show that the cellular proinflammatory response and senescence induced by CDT depend on the cytoplasmic DNA sensor cGAS through the recognition of micronuclei. Indeed, despite active cell cycle checkpoints and in contrast to other DNA damaging agents, cells exposed to CDT reach mitosis where they accumulate massive DNA damage, resulting in chromosome fragmentation and micronucleus formation in daughter cells. These phenotypes are observed with CDT from various origins and in cancer or normal cell lines. Thus, our results establish a direct link between CDT-induced DNA damage, genetic instability and the cellular inflammatory response that may be relevant in the context of natural infection associated to chronic inflammation or carcinogenesis.

\section{Introduction}

Cytolethal Distending Toxin (CDT) is a bacterial genotoxin produced by more than 30 phylogenetically distant Proteobacteria, including pathogenic strains responsible for major inflammatory diseases all over the world, like Escherichia coli (E. col), Campylobacter jejuni (C. jej), Salmonella enterica, Shigella spp., Haemophilus ducreyi (H. duc), Aggregatibacter actinomycetemcomitans (A. act) or Helicobacter spp. [1]. In 2010, CDT-producing bacteria caused 260 million foodborne illnesses worldwide, either diarrhoeal or invasive infectious diseases, resulting in 200,000 deaths [2]. While the current model supports that CDT modulates the host immune microenvironment to promote persistent bacterial colonization, the precise role of $\mathrm{CDT}$ in pathogenicity is still to be elucidated.

Several lines of evidence suggest that CDT contributes to the proinflammatory environment in the colonized tissues during bacterial infection. First, more than $80 \%$ of $H$. duc and $A$. act strains, respectively responsible for chancroid lesions and periodontitis, harbor the CDT operon [3]. In $C$. jej, the most common reported cause of human bacterial gastroenteritis, the prevalence of CDT genes is higher in strains isolated from diarrhoeal stool samples, reaching 89 to $99 \%$ [4-6]. More generally, post-infectious irritable bowel syndrome (IBS) from bacterial origins are attributable to four CDT-producing bacteria:

Campylobacter spp., Salmonella enterica, Shigella spp. or E. col[7]. Antibodies against the CDT catalytic subunit are frequently produced during inflammatory bowel disease (IBD) with diarrhea and have thus been proposed to serve as biomarkers [8]. CDT proinflammatory effects have also been depicted in rodent models. Partially purified CDT from Shigella dysenteriae is diarrheagenic and causes colonic erosions in suckling mice [9]. Moreover, only CDT-positive Helicobacter hepaticus (H. hep) were able to promote typhlocolitis in the $I L 10^{--}$mice model for IBD [10]. Of note, mice with genetically altered inflammatory responses are more susceptible to $C D T$. While an active $C D T$ toxin slightly enhances gastritis in wild-type mice infected by $C$. jej, this effect is much more pronounced in absence of NF-kB [11]. 
CDT-mediated proinflammatory responses have been studied through the release of proinflammatory mediators. In mice, production of an active CDT by $\mathrm{H}$. hep promotes the hepatic expression of TNFa, IFNg, Cox2, Interleukin-6 (IL6) and the NF-kB subunits p50 and p65 four months post-infection [12]. Interestingly, these mice latter develop hepatic dysplasic nodules ten months post-infection, questioning on possible link between CDT-mediated chronic inflammatory response and tumorigenicity. Numerous in vitro studies have confirmed that CDT-intoxicated cells produce proinflammatory cytokines [13]. When exposed to $A$. act CDT, peripheral blood mononuclear cells secrete IL-1b, IL-6, IL-8 and IFN-g [14] and macrophages secrete IL-1b, IL- 6 and TNFa [15]. Induction of proinflammatory cytokines after CDT is not restricted to immune cells. Human gingival fibroblasts treated with $A$. act CDT produce IL-6 [16]. In the same way, different colorectal cell lines treated with $C$. jej or $H$. hep CDT produce IL-8 and other cytokines in a NF-kB-dependent manner $[16,17]$. Understanding CDT proinflammatory properties is thus necessary to unravel its role during bacterial infection.

$\mathrm{CDT}$ is composed by three subunits, $\mathrm{CdtA}, \mathrm{CdtC}$ and the catalytically active CdtB, except for Salmonella enterica for which $\mathrm{CdtB}$ is associated to PItA and PItB $[18,19]$. Whatever the toxin structure, $C$ dtB catalytic activity is essential to mediate CDT-related cellular defects and pathogenicity [20]. CdtB belongs to the cation-dependent endonuclease-exonuclease-phosphatase (EEP) superfamily and has been structurally and functionally related to DNase I [18, 21]. Numerous studies have reported that the genotoxic activity exerted by CDT in a broad range of host cell lineages controls their outcome [22]. Remarkably, CDTexposed cells accumulate DNA strand breaks and therefore activate the DNA Damage Response (DDR) through ATM-CHK2 and ATR-CHK1 signaling pathways to promote cell cycle arrest and apoptotic cell death [23-25]. Cells that survive the acute phase of intoxication enter a senescent state, characterized by a permanent cell cycle arrest, persistent DDR activation, enhanced beta-galactosidase (b-Gal) activity and cell distension [26]. Interestingly, another feature of senescent cells, the senescence-associated secretory phenotype consisting in the production of cytokine [27], has also been documented after CDT-induced senescence, notably the proinflammatory mediators IL-1 $\beta$, IL-6 and IL-8.

It is therefore tempting to speculate on a correlation between DNA damage, senescence and the proinflammatory signatures generally observed in response to CDT. Indeed, unrepaired DNA lesions can result in the formation of micronuclei (MN) after cell division, which induce a proinflammatory response once sensed as cytosolic DNA by the cyclic guanosine monophosphate (GMP)-adenosine monophosphate (AMP) synthase (cGAS) [28, 29]. Activated cGAS then synthetizes cyclic GMP-AMP, a second messenger that binds the Stimulation of Interferon Genes (STING) adaptor to activate TBK1, IRF3 and NF-kB, eliciting a type I interferon (IFN) signature and promoting senescence [30].

Here, we identify cGAS as a major regulator of CDT-induced proinflammatory response and senescence. cGAS binds $M N$ in human cells chronically exposed to $C D T$, promoting a strong proinflammatory response and activation of type I IFN signaling. We show that this response depends on CdtB catalytic activity and DNA damage induction. In contrast to other genotoxic compounds, cells exposed to CDT do not primarily block at G2/M checkpoint of the cell cycle but progress through mitosis, where they suffer massive DNA damage leading to chromosome fragmentation and missegregation. This atypical 
scenario, observed with CDT from various origins in cancer or normal cell lines, results in MN formation within daughter cells. As MN are drivers of genetic instability and may sustain chronic inflammation through the CGAS-STING axis, these findings suggest that CDT modulates the host immune response and promotes tumorigenic processes mainly through $\mathrm{MN}$ formation.

\section{Results}

\section{CDT induces a proinflammatory signature related to type I interferon}

To determine wether chronic exposition to CDT induces an inflammatory response in the host, a model human cancer cell line (HeLa) was chronically exposed to $0.25 \mathrm{ng} / \mathrm{ml}$ of $E$. col CDT, inducing more than $95 \%$ cell death after 10 days (Fig. S1). The surviving fraction was cultured for 40 more days in presence of CDT and individual clones were selected as well as a pool of resistant cells (Fig. 1A). Compared to a short-term exposure, cells chronically treated to CDT (50 days total) do not show significant increase of gH2AX level, used as a surrogate of DNA damage signaling (Fig. 1B). In addition, these cells were unresponsive to the CDT-mediated G2/M checkpoint (Fig. 1C), suggesting an adaptation to the CDT toxin. However, chronically exposed-cells exhibit a higher proportion of micronucleated cells, indicative of important chromosomal instability (Fig. 1D). These cells were subjected to transcriptomic analyses and compared to two control groups, i.e. cells without treatment or chronically exposed to the CDT catalytic dead mutant, bearing the H153A substitution on CdtB, which cannot induce DNA damage nor activate DDR $[31,32]$. As depicted in the heatmap resuming expression profile of 9703 significantly regulated genes between the three conditions, individual clones and the pool of cells chronically exposed to active wild-type (WT) CDT share a common transcriptional adaptation, whereas the two control groups (nontreated and treated with mutant CDT) cannot be distinguished (Fig. 1E). The majority of the most upregulated genes, when comparing the three groups, depends on the catalytic activity of CDT rather than the presence of the toxin solely (Fig. 1F). Strikingly, the most upregulated biological processes in cells chronically exposed to WT CDT mainly rely on proinflammatory responses, more particularly to type I IFN signaling (Fig. 1G). To confirm this result, mRNA expression level of different cytokines (IL1b, IL6, IL8 and IL10) and a panel of type I IFN signaling genes (OAS1, MX1, ISG15, IFIT1, IFIT2, IFI6 and IFI44) were determined after only 2 days of CDT WT or after repeated treatment with CDT WT or H153A during 40 days (Fig. $1 \mathrm{H}$ and $1 \mathrm{I}$ ). In cells chronically exposed to CDT WT, all tested genes showed a strong mRNA expression enhancement, from 8.8-fold for IL6 to 232-fold for MX1, except the anti-inflammatory mediator IL10 for which the increase is less than 2-fold. This depends on the CdtB catalytic activity, as the H153A mutation abolishes expression profile modification. In the same way, short CDT WT exposure during 2 days does not significantly alter the expression level of any tested mRNA. Taken together, these results show that cells chronically exposed to CDT accumulate MN and display a proinflammatory response related to type I IFN signaling.

cGAS binds CDT-mediated micronuclei to promotes senescence and type I IFN signaling 
Recent reports have demonstrated that $\mathrm{MN}$ recognition by cGAS triggers innate immune activation related to type I IFN signature $[28,29]$. We thus questioned whether cGAS could bind to CDT-induced MN (Fig. 2A). In absence of treatment, $8.6 \%$ of HeLa cells are micronucleated (Fig. 2B). At $0.025 \mathrm{ng} / \mathrm{ml}$ of CDT, the proportion of cells with $\mathrm{MN}$ reaches $16.4 \%$ after $24 \mathrm{~h}$ and remains stable after $72 \mathrm{~h}$. Increasing CDT concentration to 0.25 or $2.5 \mathrm{ng} / \mathrm{ml}$ does not clearly impact the percentage of MN-containing cells at $24 \mathrm{~h}$. However, after $72 \mathrm{~h}$, the proportion of micronucleated cells increases to $34.7 \%$ with $0.25 \mathrm{ng} / \mathrm{ml}$ of CDT and $37.5 \%$ with $2.5 \mathrm{ng} / \mathrm{ml}$. These data demonstrate that prolonged CDT exposure favorizes MN formation. Then, we examined the proportion of $M N$ recognized by cGAS or stained with a $\mathrm{gH} 2 \mathrm{AX}$ antibody. After $24 \mathrm{~h}$ of CDT exposure, a dose dependent increase of gH2AX-positive MN can be observed (Fig. 2C). In contrast, the proportion of cGAS-positive MN increases only after $72 \mathrm{~h}$, with MN progressively accumulating gH2AX staining by increasing CDT concentration. Therefore, cGAS recognizes CDT-induced $\mathrm{MN}$, but this binding is delayed in time.

To better understand the role of cGAS in response to CDT injury, cGAS knockout HeLa cells $\left(c G A S^{-}\right)$were generated (Fig. 2D). $c G A S^{\circ-}$ cells are more resistant to low CDT concentrations $(0.025$ and $0.25 \mathrm{ng} / \mathrm{ml})$ than their WT cGAS counterpart (Fig. 2E). Moreover, despite similar viability loss between $c G A S^{+/+}$and $c G A S^{/-}$cells at $2.5 \mathrm{ng} / \mathrm{ml}$ of CDT, cell distention is not observed in cGAS mutant cells (Fig. 2F). In the same way, the increase of $\beta$-Gal staining, a marker of cellular senescence, is abolished in cGAS-depleted cells (Fig. 2G and $2 \mathrm{H}$ ). Finally, mRNA expression of three type I IFN signaling target genes (MX1, ISG15 and IFI44) was compared between $C G A S^{+/+}$and $c G A S^{/-}$cells after 10 days of CDT intoxication. An approximately 3-fold increased expression level of each tested gene after chronic CDT exposure was observed in $c G A S^{+/+}$but absent in $c G A S^{/-}$cells (Fig. 2I). Altogether, these results unravel the essential role of cGAS during CDT intoxication through MN recognition, eliciting cell distention, senescence and type I IFN signature.

\section{CDT-exposed cells reach mitosis despite active G2 cell cycle checkpoint}

As cGAS-mediated proinflammatory response depends on MN recognition, we next asked whether MN formation is the direct consequence of CDT intoxication. Previous studies from our lab and others showed that CDT-induced DNA damage activate the G2/M checkpoint [22]. However, G2/M checkpoint arrest is inconsistent with $\mathrm{MN}$ formation that requires mitosis completion. To explain the accumulation of MN following CDT treatment, we first monitored DNA damage markers. As DNA damage checkpoints relies on DDR activation, phosphorylation of H2AX at S139 (gH2AX), CHK1 at S345 (pCHK1) and CHK2 at T68 (pCHK2) were measured after a $24 \mathrm{~h}$ treatment with CDT (Fig. 3A). Strong DDR activation is only observed at high concentration of CDT $(2.5$ and $25 \mathrm{ng} / \mathrm{ml})$. This result supports that at low concentrations, the proliferation defects induced by CDT (Fig. S1) is unlikely the consequence of a rapid DDR activation and a checkpoint-induced cell cycle arrest. Indeed, the CDT-mediated cell cycle arrest significantly increases from 24 to $72 \mathrm{~h}$ (Fig. 3B), implying that at least a part of CDT-exposed cells reach mitosis before to block their cell cycle during the next rounds of cell division. In contrast, exposure to etoposide (etop), camptothecin (campto) or mitomycin C (MMC), three other genotoxic compounds, 
induces a rapid and stable cell cycle block over time (Fig. S2). To test whether DDR does not effectively abrogate cell proliferation during early phase of CDT intoxication, cells were co-exposed during $24 \mathrm{~h}$ to CDT and ATR inhibitor VE-821 (ATRi), given that the G2/M checkpoint mostly depends on ATR rather than ATM under these conditions (Fig. S3). Contrary to other genotoxic treatments, ATR inactivation does not sensitize HeLa cells to CDT during the first $24 \mathrm{~h}$ of exposure (Fig. $3 \mathrm{C}$ ), further supporting that cells do not activate checkpoint during early phase of CDT intoxication. Moreover, while exposure to control genotoxicants or high CDT concentration $(25 \mathrm{ng} / \mathrm{ml}$ ) block mitotic entry in an ATR-dependent manner, indicative of active G2 checkpoint, lowest CDT concentrations significantly increase the mitotic index, confirming that cells do progress through mitosis (Fig. 3D). This result demonstrates that ATR is only crucial after high treatment with CDT to protect cells from mitotic catastrophe by inducing a G2/M arrest, at least during the first $24 \mathrm{~h}$ of exposure. Finally, in contrast to high CDT concentrations or DNA damaging agents, low CDT concentrations $(0.025$ and $0.25 \mathrm{ng} / \mathrm{ml})$ induce $\mathrm{MN}$ formation that is not aggravated by the presence of ATRi (Fig. 3E). Altogether, these data demonstrate that except for high concentrations, CDT exposure allows mitotic entry and MN generation, despite the presence of active cell cycle checkpoints.

\section{CDT induces mitotic delay and cell death}

The increased mitotic index observed in CDT-exposed cells (Fig. 3D) is accompanied by a dose-dependent diminution of the anaphase population (Fig. 3F). In order to gain insight into the mitotic phenotype of CDT-treated cells, live-cell imaging has been performed on HeLa cells stably expressing the chromatibody fused to GFP, enabling real-time chromatin visualization [33]. When measuring the timing needed to complete metaphase, we found that unperturbed mitosis takes an average of $64 \mathrm{~min}$ that significantly increases to 109 and $164 \mathrm{~min}$ after treatment with $0.25 \mathrm{ng} / \mathrm{ml}$ and $2.5 \mathrm{ng} / \mathrm{ml}$ of CDT respectively (Fig. 3G). Moreover, monitoring cell death during the course of live imaging revealed that an important fraction of CDT-exposed cells preferentially dies at metaphase (Fig. $3 \mathrm{H}$ ). In conclusion, mitotic cells are particularly affected during CDT intoxication, as evidenced by a prolonged metaphase duration that eventually result in cell death.

\section{CDT-exposed cells experience DNA damage at mitosis}

To better understand the relationship between CDT-mediated DNA damage and cell cycle defects, cell cycle analyses were conducted after immunostaining with antibodies directed against gH2AX and $\mathrm{H} 3$ histone phosphorylated at $\mathrm{S} 10(\mathrm{pH} 3)$ to identify mitotic cells. Cells treated with CDT for $24 \mathrm{~h}$ present a dose-dependent augmentation of $\mathrm{pH} 3$ and $\mathrm{gH} 2 \mathrm{AX}$ positive cells, representing a 12-fold increase at 2.5 $\mathrm{ng} / \mathrm{ml}$ of CDT compared to control cells. In contrast, after exposure with moderate concentration of control genotoxic compounds, only cells without gH2AX staining do progress to mitosis (Fig. 4A). Thus, CDT-exposed cells progress through mitosis with damaged DNA, representing a unique feature over other genotoxic insult. Strikingly, asynchronous cells exposed to CDT display an intense gH2AX signal in mitosis compared to interphase (Fig. 4B). This staining is clearly distinguishable from the basal DNA damage-independent gH2AX signal described in unchallenged mitotic cells [34], that is diffuse all along 
the condensed chromosomes from prometaphase to anaphase, or from few gH2AX foci observed in mitotic cells exposed to other DNA damaging agents (Fig. S4). The huge gH2AX increase at mitosis is observed with CDT from other bacterial origins or with other cell lines (Fig. S5), thus representing a general cellular response to $\mathrm{CDT}$. Moreover, the fraction of $\mathrm{gH} 2 \mathrm{AX}$-positive cells is more important in mitosis compared to interphase, after $24 \mathrm{~h}$ or even a shorter incubation of $8 \mathrm{~h}$ with CDT (Fig. 4C), demonstrating that mitotic cells represent the first population to be damaged during the course of CDT treatment. The strong gH2AX signal after CDT can be observed all along the mitotic phases (Fig. 4D). Finally, CDT exposure induces a dose-dependent increase of chromosome fragments that does not properly align during metaphase or segregate at anaphase (Fig. 4E), therefore explaining the high level of MN observed after CDT treatment.

\section{CDT induces DNA double-strand breaks during mitosis}

To exclude the possibility that mitotic $\mathrm{gH} 2 \mathrm{AX}$ signal originates from DNA damage induced before mitotic entry, HeLa cells were enriched in mitosis by a $22 \mathrm{~h}$ nocodazole block and then co-exposed during the last $6 \mathrm{~h}$ to CDT or genotoxic control agents. Similar to observations made on asynchronous cells, cells treated with CDT during mitosis exhibit a strong gH2AX level compared to etop, campto or MMC (Fig. 5A). To confirm that the gH2AX level increase in mitosis depends on DSB induction, cells arrested in mitosis were exposed to CDT before to be subjected to neutral comet assay (Fig. 5B). Mitotic cells treated with 0.25 or $2.5 \mathrm{ng} / \mathrm{ml}$ of CDT show a significant increase in comet tail moment (Fig. $5 \mathrm{C}$ ). Taken together, these data demonstrate that CDT induces DSB during mitosis leading to chromosome fragmentation and missegregation.

\section{CDT promotes proinflammatory response and mitotic defects in normal colonic epithelial cells}

We next assessed whether non-transformed cells exhibit similar inflammatory responses to CDT genotoxic activity. Immortalized normal human colonic epithelial cells (HCECs), previously shown to be susceptible to CDT intoxication [35], were exposed to CDT for $96 \mathrm{~h}$ and STAT1 phosphorylation at Y701 (pSTAT1) was measured as a surrogate for inflammatory pathway activation after DNA damage [28]. HCECs cells show a dose dependent increase of pSTAT1 (Fig. 6A), confirming that CDT activates inflammatory pathway in non-transformed cells. CDT also induces senescence in HCEC cells, as evidenced by $\beta$-Gal staining (Fig. 6B and C). Importantly, the proportion of $\beta$-Gal positive cells decreases when adding CDK1 inhibitor RO-3306 (CDK1i), which blocks cells at G2/M boundary, supporting that CDTtreated cells must go through mitosis before entering a senescent state. Compared to control displaying only $4 \%$ of micronucleated cells, a $24 \mathrm{~h}$ exposure to CDT enables MN formation in approximately $16 \%$ of HCEC cells (Fig. 6D). This result indicates that normal cells do not stop at G2/M checkpoint during early course of CDT intoxication, but divide and form MN in daughter cells. Moreover, CDT-induced pSTAT1 increase is prevented by STING inhibitor H-151 (STINGi) (Fig. 6E), suggesting that similarly to HeLa cells, MN formed in HCEC cells in response to CDT activate the CGAS-STING axis to enhance proinflammatory responses. We further explored the mitotic phenotype of CDT-exposed HCEC cells and observed a decrease of the anaphase population in cells exposed to $0.25 \mathrm{ng} / \mathrm{ml}$ of CDT (Fig. 6F), as shown above 
(Fig. 3F). Moreover, mitotic HCEC cells displayed the same intense gH2AX signal as in cancer cell lines (Fig. 6G). Finally, the proportion of gH2AX positive cells after an $8 \mathrm{~h}$ treatment to $0.025 \mathrm{ng} / \mathrm{ml}$ of CDT is significantly higher in mitosis compared to interphase (Fig. 6H). Taken together, these data highlight the crucial role of CGAS-STING pathways in proinflammatory activation in normal HCEC cells, and demonstrate that this requires passage through mitosis where chromosomes accumulate DNA damage and form $\mathrm{MN}$ in daughter cells.

\section{Discussion}

The discovery of CDT more than 30 years ago relied on the distinctive phenotype of progressive cytoplasmic and nuclear enlargement this toxin caused in cultured mammalian cells [36]. This cell distention and other features of CDT exposure, namely proinflammatory cytokines expression or permanent DDR activation with cell cycle arrest, have then been associated to cellular senescence [26]. Our study now establishes a direct link between all these CDT-mediated cellular outcomes and the cytosolic DNA sensor cGAS recognizing MN that, at least in part, may arise from DNA damage induced during mitosis.

Mitosis coordinates the proper segregation of sister chromatids to ensure faithful transmission of equal genetic material to the next cell generation. On the other side, DSB repair is inhibited during mitosis, through the phosphorylation of several DDR factors by CDK1 and PLK1 kinases, noticeably to prevent telomere fusion [37]. Therefore, controlling chromosome integrity prior separation is performed at the previous $\mathrm{G} 2$ phase and implies cell cycle arrest and DNA repair to impede transition to mitosis with damaged DNA [38]. As duration of $M$ phase is short and constant [39], only a very minor part of cells from an asynchronous population may suffer DNA damage at mitosis. The data presented here depict an atypical scenario with CDT-treated cells being able to reach mitosis despite continuous DNA damage induction. Contrary to ionizing radiations that instantaneously induce massive DNA damage, or to chemicals and metabolites from pathogens with limited stability or capacity to induce repeated lesions, the CDT catalytic subunit CdtB may exert unceasing genotoxic attacks, given that its nuclease activity remains active for at least $48 \mathrm{~h}$ after cellular internalization [25,32]. CDT is the only characterized encoded toxin from mammalian pathogens that has evolved to create DSBs in host genomic DNA [40]. This continuous nuclease activity is opposed to the host DNA repair machinery, implying that under a certain threshold, CDT-induced DNA damage do not effectively activate the DDR and therefore allows G2/M transition. In this context, previous studies used most of the time CDT concentration around 1 $\mathrm{mg} / \mathrm{ml}$ and beyond, resulting in substantial cell cycle arrest at the $\mathrm{G} 2$ checkpoint. Similar effects have been observed here in HeLa cells with $25 \mathrm{ng} / \mathrm{ml}$ of CDT within the first $24 \mathrm{~h}$ of exposure, whereas a 1000fold lower concentration does not strongly activate the DDR nor alter cell cycle, but still induces DNA damage, chromosome fragmentation and a delay at mitosis followed by increased MN formation and eventually viability loss. Currently, the physiological concentration of CDT to which cells are exposed during a natural infection is unknown, but one may expect that the cellular effects caused by moderate concentrations of toxin used in this study should be at least as relevant than analyzing highest doses. 
We demonstrate here that once entered in mitosis, CDT-treated cells experience massive DNA damage, as evidenced by the intense mitotic $\mathrm{gH} 2 \mathrm{AX}$ staining observed in several human cell lines, with toxins from various bacterial origins. This indicates that inflicting DNA lesion during mitosis is a general mode of action of CDT in proliferative cells. The gH2AX signal in mitosis is correlated to a dose-dependent increase of mitotic cells with chromosome fragments, as revealed by microscopic observation or neutral comet assay. These DNA damage impose a dose-dependent mitotic delay at metaphase, similar to cells depleted for the mitotic resolvase GEN1 [41, 42]. More generally, mitotic duration is governed by the capacity of cells to dissolve or resolve Hollyday junctions [43], questioning on CdtB abilities to target homologous recombination intermediates that are processed later in mitosis.

We speculate that the progressive accumulation of DNA damage, during at least $48 \mathrm{~h}$, in interphasic CDTexposed cells [31] may partly be a consequence of unrepaired DNA lesions transmitted from the previous cell division. In comparison, control genotoxic compounds induce only few mitotic DSBs at selected concentrations that only partially block cells in G2, in an ATR-dependent manner. Etoposide at $10 \mathrm{mM}$ has been shown to induce important DNA damage on mitotic HeLa cells, however synchronization in mitosis is required to ensure that an important proportion of cells is affected [44]. Alternatively, HT-29 cells arrested in $\mathrm{G} 2$ after a $25 \mathrm{nM}$ treatment of camptothecin, a concentration that is comparable to the present study, finally reach mitosis $48 \mathrm{~h}$ post-treatment with highly damaged chromatin [45]. Such recovery from G2 arrest in the presence of DNA damage, referred to as checkpoint adaptation, has been observed with many DNA damaging agents and give rise to important MN formation in post-mitotic cells [46]. In the same way, a substantial increase of micronucleated cells treated with etop, campto or MMC was also observed here at $72 \mathrm{~h}$ (data not shown). Therefore, CDT exposure globally recapitulates the phenotype of cells subjected to checkpoint adaptation, but with more rapid kinetics due to a weak ATR-dependent G2 checkpoint activation.

The cGAS-STING axis activates IRF3 and NF-KB, two transcriptional inducers of type I IFNs and other cytokines [30]. cGAS has also been shown to play a crucial role during cellular senescence induced by DNA damage [47]. Therefore, our findings that HeLa cells chronically exposed to CDT display high MN frequency and type I IFN signature prompted us to examine the role of cGAS in response to CDT genotoxin. Our data reveal that $c G A S^{--}$cells are resistant to low CDT concentrations and cannot induce the expression of type I IFN signaling target genes. Moreover, cGAS deficiency prevents CDT-mediated cell distention and senescence. These findings support that cGAS impedes the proliferation of cells experiencing genetic instability after CDT exposure by inducing senescence. However, we cannot exclude that in CDT-exposed cells, cGAS inhibits DSB repair and/or promotes mitotic cell death upon retardation of metaphase-anaphase transition [48, 49], therefore participating in the sensitivity to CDT. Finally, we bring evidence that non-transformed cells display similar behavior in response to CDT-mediated MN formation, with mitosis-dependent senescence induction and STING-dependent proinflammatory pathway activation. Thus, our data indicate that normal proliferative cells may influence the modulation of the immune environment in tissues infected by CDT-producing bacteria. 
Persistent infection causes chronic inflammation, a driving force of tumor development [50]. CDT production during bacterial infection promotes inflammation and persistent colonization, and may eventually contribute to tumorigenesis [10-12, 51]. In a broad range of cellular lineages, CDT intoxination induces DNA damage and a proinflammatory signature [13], but how these two events are linked was never addressed so far. Our findings identify cGAS as the missing piece between CDT genotoxic and immunomodulatory activities. cGAS is a key modulator of the innate immune response that can influence the tumor microenvironment in ways that may be detrimental or beneficial [52]. Further investigations will be necessary to unravel the role of the cGAS-dependent surveillance of MN during natural infection with CDT producing bacteria.

\section{Materials And Methods}

\section{Cell culture and treatments}

HeLa cells (HeLa-S3 cells, ATCC) were cultured in DMEM (Life Technologies), supplemented with 10\% heat-inactivated fetal bovine serum (FBS, Gibco) and $1 \%$ antibiotics (penicillin/streptomycin). Human colonic epithelial cell (HCECs), generated and provided by Pr Jerry W Shay, were cultured as previously described [35] in 4:1 high-glucose DMEM/medium 199 supplemented with 2\% FBS, epidermal growth factor $(20 \mathrm{ng} / \mathrm{ml})$, hydrocortisone $(1 \mathrm{mg} / \mathrm{ml})$, insulin $(10 \mathrm{mg} / \mathrm{ml})$, transferrin $(2 \mathrm{mg} / \mathrm{ml})$, sodium selenite $(5$ $\mathrm{nM})$, and Gentamycin sulfate $(50 \mu \mathrm{g} / \mathrm{ml})$. Cells were maintained at $37^{\circ} \mathrm{C}$ in a humidified atmosphere containing $5 \% \mathrm{CO} 2$, and subcultured approximately every $2-3$ days.

E.co/ CDT (WT or the catalytic dead mutant $\mathrm{H} 153 \mathrm{~A}$ ) were produced and purified as previously described (Fedor et al., 2013). ATM inhibitor KU-55933 (ATMi), ATR inhibitor VE-821 (ATRi), CDK1 inhibitor RO-3306 (CDK1i) and STING inhibitor H-151 (STINGi) were purchased from Selleckchem. ATMi and ATRi were used at a final concentration of $10 \mathrm{mM}, \mathrm{CDKi}$ at $9 \mathrm{mM}$ and STINGi at $0.5 \mathrm{mM}$. All other chemicals and reagents were purchased from Sigma-Aldrich.

\section{Western blot analyses}

Cells were incubated on ice for $30 \mathrm{~min}$ in lysis buffer $(50 \mathrm{mM}$ Tris- $\mathrm{HCl} \mathrm{pH} 7.5,500 \mathrm{mM} \mathrm{NaCl}$ and $0.5 \%$ NP40) containing the HaltTM Protease \& Phosphatase inhibitor cocktail (Thermo Scientific) and sonicated on a VibraCell 72434 (Bioblock Scientific). Cell lysates were centrifugated and the supernatant containing total soluble proteins was kept. Proteins were separated by SDS-PAGE and transferred to a nitrocellulose membrane (Amersham). Membranes were incubated with the primary antibody over-night at $4^{\circ} \mathrm{C}$. $\mathrm{yH} 2 \mathrm{AX}$ antibody was purchased from Merck/Millipore (05-636), pChk1 (133D3), pChk2 (C13C1), pH3 (D2C8), cGAS (D1D3G) and pSTAT1 (58D6) antibodies from Cell Signaling and GAPDH

(GTX100118) antibody from GeneTex. The secondary anti-mouse or anti-rabbit HRP-conjugated antibodies (Jackson Immunoresearch laboratories) were incubated for $1 \mathrm{~h}$ at room temperature. Proteins were visualized with the enhanced chemiluminescence substrate ECL (Biorad) and imaged using the ChemiDoc XRS Biorad Imager and Image Lab Software. 
Cells were grown on glass coverslips. After at least $24 \mathrm{~h}$ of culture, cells were fixed with $4 \%$ paraformaldehyde, permeabilized with $0.5 \%$ Triton X-100, blocked with $3 \%$ BSA and $0.05 \%$ IGEPAL, and stained with primary antibodies for $2 \mathrm{~h}$ at room temperature in blocking solution (all solutions were prepared in PBS). Cells were washed three times with PBS 0.05\% IGEPAL and incubated with the secondary antibodies for $1 \mathrm{~h}$ (Alexa Fluor 488 Goat anti-mouse (A32723) or Alexa Fluor 594 anti-rabbit (A32740), purchased from Invitrogen). DNA was stained with 4.6-diamino-2-phenyl indole (DAPI) $30 \mathrm{nM}$. Coverslips were mounted onto slides with PBS-glycerol (90\%) containing $1 \mathrm{mg} / \mathrm{ml}$ paraphenylenediamine and observed at 40x magnification with a Nikon 50i fluorescence microscope equipped with a Luca $S$ camera. Cells were counted positive for foci formation when $>10 \mathrm{foci} /$ interphase nuclei or when $>5$ foci/mitotic nuclei were detected.

\section{Cell viability assays}

For clonogenic assay, cells were plated in triplicate at a density of 300 to 3000 cells per well in 6 wells plate. One day after seeding, cells were treated and grown for 10 days. Formed colonies were fixed and stained with a $0.25 \%$ methylene blue and $100 \%$ methanol solution. Colonies containing more than 50 cells were counted and the surviving rate calculated.

For rapid viability testing at $24 \mathrm{~h}$, cells were plated in triplicate at a density of 10000 per well in 96 wells plate. One day after seeding, cells were treated and grown for $24 \mathrm{~h}$. Viability was assessed using the CellT iter-Glo ${ }^{\circledR}$ Luminescent Cell Viability Assay (Promega) according to the manufacturer's instructions.

Senescence assay

The senescence-associated b-galactosidase staining was performed using the Senescence bGalactosidase Staining Kit (Cell Signaling) according to the manufacturer's instructions. Images were captured by light microscopy.

\section{Flow cytometry analyses}

Cells were fixed with $4 \%$ paraformaldehyde for $15 \mathrm{~min}$ at room temperature in PBS. For immunostaining, fixed cells were permeabilized with $0.2 \%$ triton X-100 and 1\% BSA in PBS for 20 min at room temperature. Antibodies against $\mathrm{yH} 2 \mathrm{AX}$ and $\mathrm{pH} 3$ were incubated for $2 \mathrm{~h}$ in $1 \% \mathrm{BSA}$ at room temperature. After three washes, cells were incubated with the secondary antibodies Alexa Fluor 488 anti-mouse and Alexa Fluor 594 anti-rabbit for $30 \mathrm{~min}$ at room temperature. Then, cells were washed three times and incubated in PBS containing DAPI ( $1 \mu \mathrm{g} / \mathrm{mL})$ for 15 min before samples were processed using flow cytometry (MACSQuant, Miltenyi Biotec). At least 10000 events were analyzed per sample using FlowLogic software (Miltenyi Biotec). 
Cells were treated for $18 \mathrm{~h}$ with $2 \mathrm{mM}$ thymidine, washed twice with PBS and released in fresh media for $9 \mathrm{~h}$. Cells were treated again with $2 \mathrm{mM}$ thymidine for $17 \mathrm{~h}$ to be synchronized in early S, washed twice with PBS and released in fresh media for $6 \mathrm{~h}$ before adding $50 \mathrm{ng} / \mathrm{ml}$ nocodazole. After $4 \mathrm{~h}$, mitotic cells were collected by shake-off and exposed for $12 \mathrm{~h}$ to CDT or the genotoxic controls in presence of nocodazole. Comet assay was performed in neutral conditions using the Comet SCGE assay kit (Enzo) according to the manufacturer's instructions. At least 60 cells were analyzed per sample using OpenComet software.

\section{Time-lapse imaging}

HeLa cells stably expressing the chromatibody-GFP to visualize chromatin in living cells (Jullien et al., 2016) were generated by TALEN insertion at AAVS1 site with co-transfection of SHDP-CMV-VHH-HA-GFP donor plasmid and AAVS1 right and left Talen plasmids (genome TALER AAVS1 safe harbor cloning kit, Genecopoeia) using TransIT-LT1 (MirusBio) according to manufacturer's instructions. Cells were plated in 4-compartments Petri dish (CellView Greiner Bio-One). Immediately after treatment, time-lapse fluorescent microscopy was performed with a Zeiss Axio-observer inverted videomicroscope with controlled temperature $\left(37^{\circ} \mathrm{C}\right), \mathrm{CO} 2$ level $(5 \%)$ and humidity. Images were acquired for 90 h every 9 minutes with an AxioCam 506 camera (Zeiss) in two focal planes $5 \mu \mathrm{M}$ apart from each other. Illumination has been set to 75 ms with $20 \%$ laser intensity to reduce phototoxicity. The two focal planes were flattened and 100 to 200 mitosis per sample were analyzed with FIJI software from 4 to $90 \mathrm{~h}$ post-exposure to measure the duration of mitotic phases and cell death.

\section{Generation of cGAS knock-out HeLa cells}

The CRISPR plasmid was a generous gift from J. Dupuy (Toxalim, France). The donor plasmid (pCMVCas9-GFP, Sigma), containing the sgRNA, Cas9 and GFP, was modified to substitute the sgRNA sequence for cGAS sgRNA 1 (5'- GCTTCCGCACGGAATGCCAGG) or CGAS sgRNA 2 (5'-

CGATGGATCCCACCGAGTCT) targeting the first exon of the CGAS gene, using the Q5 site-directed mutagenesis kit (New England Biolabs) according to manufacturer's instructions. The two plasmids bearing CGAS sgRNA1 and 2 were co-transfected in HeLa cells using TransIT-LT1 (MirusBio) according to manufacturer's instructions. Individual clones were selected by cGAS immunofluorescence and confirmed by Western blot analyses. Two confirmed $c G A S^{-}$clones were used in this study.

\section{Gene expression}

Total RNA was extracted with TRIzol reagent (Invitrogen, Carlsbad, CA, USA) mRNA were extracted and the quality of these samples was assessed (Agilent RNA 6000 Nano Kit Quick, Agilent Bioanalyzer 2100); RNA Integrity Number (RIN) of these mRNA was superior to 9.8 .

For transcriptomic data, gene expression profiles were obtained at the GeT-TRiX facility (GénoToul, Génopole Toulouse Midi-Pyrénées, France) using Agilent SurePrint G3 Human GE v2 microarrays (8x60K, design 039494) following the manufacturer's instructions. For each sample, Cyanine-3 (Cy3) labeled 
cRNA was prepared from $200 \mathrm{ng}$ of total RNA using the One-Color Quick Amp Labeling kit (Agilent Technologies) according to the manufacturer's instructions, followed by Agencourt RNAClean XP (Agencourt Bioscience Corporation, Beverly, Massachusetts). Dye incorporation and cRNA yield were checked using Dropsense ${ }^{\text {TM }} 96$ UV/VIS droplet reader (Trinean, Belgium). 600 ng of Cy3-labelled cRNA were hybridized on the microarray slides following the manufacturer's instructions. Immediately after washing, the slides were scanned on Agilent G2505C Microarray Scanner using Agilent Scan Control A.8.5.1 software and fluorescence signal extracted using Agilent Feature Extraction software v10.10.1.1 with default parameters.

For real-time quantitative polymerase chain reaction (qPCR), $2 \mu \mathrm{g}$ RNA samples were reverse-transcribed using the High-Capacity cDNA Reverse Transcription Kit (Applied Biosystems). qPCR was performed using the Power SYBR ${ }^{\circledR}$ Green PCR Master Mix and an ABI Prism 7300 Sequence Detection System instrument and software (Applied Biosystems). Sequences of the primers are listed in supplementary Table 1. All samples were run in triplicate. qPCR data were normalized to TBP1 mRNA levels and analyzed with LinRegPCR.v2015.3.

\section{Statistical analysis}

Microarray data were analyzed using $\mathrm{R}$ and Bioconductor packages [53]. Raw data (median signal intensity) were filtered, log2 transformed, and normalized using quantile method [54]. A model was fitted using the limma ImFit function [55]. Pair-wise comparisons between biological conditions were applied using specific contrasts. A correction for multiple testing was applied using Benjamini-Hochberg procedure to control the False Discovery Rate (FDR). Probes with FDR $\leq 0.05$ were considered to be differentially expressed between conditions. Hierarchical clustering was applied to the samples and the differentially expressed probes using 1-Pearson correlation coefficient as distance and Ward's criterion for agglomeration.

Other statistical analyses were assessed using Prism 8 software (GraphPad). Differential effects were analyzed by one-way or two-way analysis of variance (ANOVA) followed by appropriate post-hoc tests (Sidak or Dunnett). A p value $<0.05$ was considered significant $\left({ }^{\star} p<0.05 ;{ }^{* \star} p<0.01 ; * \star \star p<0.001\right.$; ${ }^{\star \star \star \star} p$ $<0.0001)$.

\section{Declarations}

1. Jinadasa RN, Bloom SE, Weiss RS, Duhamel GE (2011) Cytolethal distending toxin: a conserved bacterial genotoxin that blocks cell cycle progression, leading to apoptosis of a broad range of mammalian cell lineages. Microbiology (Reading, Engl) 157:1851-1875. https://doi.org/10.1099/mic.0.049536-0

2. World Health Organization (2015) WHO estimates of the global burden of foodborne diseases: foodborne disease burden epidemiology reference group 2007-2015, World Health Organization 
3. Ahmed HJ, Svensson LA, Cope LD, et al (2001) Prevalence of cdtABC genes encoding cytolethal distending toxin among Haemophilus ducreyi and Actinobacillus actinomycetemcomitans strains. J Med Microbiol 50:860-864. https://doi.org/10.1099/0022-1317-50-10-860

4. Redondo N, Carroll A, McNamara E (2019) Molecular characterization of Campylobacter causing human clinical infection using whole-genome sequencing: Virulence, antimicrobial resistance and phylogeny in Ireland. PLoS One 14:e0219088. https://doi.org/10.1371/journal.pone.0219088

5. Barakat AMA, El-Razik KAA, Elfadaly HA, et al (2020) Prevalence, molecular detection, and virulence gene profiles of Campylobacter species in humans and foods of animal origin. Vet World 13:14301438. https://doi.org/10.14202/vetworld.2020.1430-1438

6. Wysok B, Wojtacka J, Hänninen M-L, Kivistö R (2020) Antimicrobial Resistance and VirulenceAssociated Markers in Campylobacter Strains From Diarrheic and Non-diarrheic Humans in Poland. Front Microbiol 11:1799. https://doi.org/10.3389/fmicb.2020.01799

7. Klem F, Wadhwa A, Prokop LJ, et al (2017) Prevalence, Risk Factors, and Outcomes of Irritable Bowel Syndrome After Infectious Enteritis: A Systematic Review and Meta-analysis. Gastroenterology 152:1042-1054.e1. https://doi.org/10.1053/j.gastro.2016.12.039

8. Rezaie A, Park SC, Morales W, et al (2017) Assessment of Anti-vinculin and Anti-cytolethal Distending Toxin B Antibodies in Subtypes of Irritable Bowel Syndrome. Dig Dis Sci 62:1480-1485. https://doi.org/10.1007/s10620-017-4585-z

9. Okuda J, Fukumoto M, Takeda Y, Nishibuchi M (1997) Examination of diarrheagenicity of cytolethal distending toxin: suckling mouse response to the products of the cdtABC genes of Shigella dysenteriae. Infect Immun 65:428-433. https://doi.org/10.1128/IAI.65.2.428-433.1997

10. Pratt JS, Sachen KL, Wood HD, et al (2006) Modulation of host immune responses by the cytolethal distending toxin of Helicobacter hepaticus. Infect Immun 74:4496-4504. https://doi.org/10.1128/IAl.00503-06

11. Fox JG, Rogers AB, Whary MT, et al (2004) Gastroenteritis in NF-kappaB-deficient mice is produced with wild-type Camplyobacter jejuni but not with $\mathrm{C}$. jejuni lacking cytolethal distending toxin despite persistent colonization with both strains. Infect Immun 72:1116-1125. https://doi.org/10.1128/iai.72.2.1116-1125.2004

12. Ge Z, Rogers AB, Feng Y, et al (2007) Bacterial cytolethal distending toxin promotes the development of dysplasia in a model of microbially induced hepatocarcinogenesis. Cell Microbiol 9:2070-2080. https://doi.org/10.1111/j.1462-5822.2007.00939.x

13. Martin OCB, Frisan T (2020) Bacterial Genotoxin-Induced DNA Damage and Modulation of the Host Immune Microenvironment. Toxins (Basel) 12:. https://doi.org/10.3390/toxins12020063

14. Akifusa S, Poole S, Lewthwaite J, et al (2001) Recombinant Actinobacillus actinomycetemcomitans cytolethal distending toxin proteins are required to interact to inhibit human cell cycle progression and to stimulate human leukocyte cytokine synthesis. Infect Immun 69:5925-5930. https://doi.org/10.1128/iai.69.9.5925-5930.2001 
15. Shenker BJ, Walker LP, Zekavat A, et al (2014) Blockade of the PI-3K signalling pathway by the Aggregatibacter actinomycetemcomitans cytolethal distending toxin induces macrophages to synthesize and secrete pro-inflammatory cytokines. Cell Microbiol 16:1391-1404. https://doi.org/10.1111/cmi.12299

16. Belibasakis GN, Johansson A, Wang Y, et al (2005) Cytokine responses of human gingival fibroblasts to Actinobacillus actinomycetemcomitans cytolethal distending toxin. Cytokine 30:56-63. https://doi.org/10.1016/j.cyto.2004.11.008

17. Zheng J, Meng J, Zhao S, et al (2008) Campylobacter-induced interleukin-8 secretion in polarized human intestinal epithelial cells requires Campylobacter-secreted cytolethal distending toxin- and Toll-like receptor-mediated activation of NF-kappaB. Infect Immun 76:4498-4508. https://doi.org/10.1128/IAl.01317-07

18. Nesić D, Hsu Y, Stebbins CE (2004) Assembly and function of a bacterial genotoxin. Nature 429:429433. https://doi.org/10.1038/nature02532

19. Song J, Gao X, Galán JE (2013) Structure and function of the Salmonella Typhi chimaeric A(2)B(5) typhoid toxin. Nature 499:350-354. https://doi.org/10.1038/nature12377

20. Pons BJ, Vignard J, Mirey G (2019) Cytolethal Distending Toxin Subunit B: A Review of StructureFunction Relationship. Toxins (Basel) 11:. https://doi.org/10.3390/toxins11100595

21. Elwell CA, Dreyfus LA (2000) DNase I homologous residues in CdtB are critical for cytolethal distending toxin-mediated cell cycle arrest. Mol Microbiol 37:952-963. https://doi.org/10.1046/j.1365-2958.2000.02070.x

22. Bezine E, Vignard J, Mirey G (2014) The cytolethal distending toxin effects on Mammalian cells: a DNA damage perspective. Cells 3:592-615. https://doi.org/10.3390/cells3020592

23. Cortes-Bratti X, Karlsson C, Lagergård T, et al (2001) The Haemophilus ducreyi cytolethal distending toxin induces cell cycle arrest and apoptosis via the DNA damage checkpoint pathways. J Biol Chem 276:5296-5302. https://doi.org/10.1074/jbc.M008527200

24. Frisan T, Cortes-Bratti X, Chaves-Olarte E, et al (2003) The Haemophilus ducreyi cytolethal distending toxin induces DNA double-strand breaks and promotes ATM-dependent activation of RhoA. Cell Microbiol 5:695-707. https://doi.org/10.1046/j.1462-5822.2003.00311.x

25. Fahrer J, Huelsenbeck J, Jaurich $\mathrm{H}$, et al (2014) Cytolethal distending toxin (CDT) is a radiomimetic agent and induces persistent levels of DNA double-strand breaks in human fibroblasts. DNA Repair (Amst) 18:31-43. https://doi.org/10.1016/j.dnarep.2014.03.002

26. Blazkova H, Krejcikova K, Moudry P, et al (2010) Bacterial intoxication evokes cellular senescence with persistent DNA damage and cytokine signalling. J Cell Mol Med 14:357-367. https://doi.org/10.1111/j.1582-4934.2009.00862.x

27. Rodier F, Coppé J-P, Patil CK, et al (2009) Persistent DNA damage signalling triggers senescenceassociated inflammatory cytokine secretion. Nat Cell Biol 11:973-979. https://doi.org/10.1038/ncb1909 
28. Harding SM, Benci JL, Irianto J, et al (2017) Mitotic progression following DNA damage enables pattern recognition within micronuclei. Nature 548:466-470. https://doi.org/10.1038/nature23470

29. Mackenzie KJ, Carroll P, Martin C-A, et al (2017) cGAS surveillance of micronuclei links genome instability to innate immunity. Nature 548:461-465. https://doi.org/10.1038/nature23449

30. Li T, Chen ZJ (2018) The cGAS-cGAMP-STING pathway connects DNA damage to inflammation, senescence, and cancer. J Exp Med 215:1287-1299. https://doi.org/10.1084/jem.20180139

31. Fedor Y, Vignard J, Nicolau-Travers M-L, et al (2013) From single-strand breaks to double-strand breaks during S-phase: a new mode of action of the Escherichia coli Cytolethal Distending Toxin. Cell Microbiol 15:1-15. https://doi.org/10.1111/cmi.12028

32. Bezine E, Malaisé Y, Loeuillet A, et al (2016) Cell resistance to the Cytolethal Distending Toxin involves an association of DNA repair mechanisms. Sci Rep 6:36022. https://doi.org/10.1038/srep36022

33. Jullien D, Vignard J, Fedor Y, et al (2016) Chromatibody, a novel non-invasive molecular tool to explore and manipulate chromatin in living cells. J Cell Sci 129:2673-2683. https://doi.org/10.1242/jcs.183103

34. Ichijima Y, Sakasai R, Okita N, et al (2005) Phosphorylation of histone H2AX at M phase in human cells without DNA damage response. Biochem Biophys Res Commun 336:807-812. https://doi.org/10.1016/j.bbrc.2005.08.164

35. Graillot V, Dormoy I, Dupuy J, et al (2016) Genotoxicity of Cytolethal Distending Toxin (CDT) on Isogenic Human Colorectal Cell Lines: Potential Promoting Effects for Colorectal Carcinogenesis. Front Cell Infect Microbiol 6:34. https://doi.org/10.3389/fcimb.2016.00034

36. Johnson WM, Lior H (1988) A new heat-labile cytolethal distending toxin (CLDT) produced by Escherichia coli isolates from clinical material. Microb Pathog 4:103-113. https://doi.org/10.1016/0882-4010(88)90052-6

37. Orthwein A, Fradet-Turcotte A, Noordermeer SM, et al (2014) Mitosis inhibits DNA double-strand break repair to guard against telomere fusions. Science 344:189-193. https://doi.org/10.1126/science.1248024

38. Blackford AN, Stucki M (2020) How Cells Respond to DNA Breaks in Mitosis. Trends Biochem Sci 45:321-331. https://doi.org/10.1016/j.tibs.2019.12.010

39. Araujo AR, Gelens L, Sheriff RSM, Santos SDM (2016) Positive Feedback Keeps Duration of Mitosis Temporally Insulated from Upstream Cell-Cycle Events. Mol Cell 64:362-375. https://doi.org/10.1016/j.molcel.2016.09.018

40. Weitzman MD, Weitzman JB (2014) What's the damage? The impact of pathogens on pathways that maintain host genome integrity. Cell Host Microbe 15:283-294. https://doi.org/10.1016/j.chom.2014.02.010

41. Rodrigue A, Coulombe $Y$, Jacquet $K$, et al (2013) The RAD51 paralogs ensure cellular protection against mitotic defects and aneuploidy. J Cell Sci 126:348-359. https://doi.org/10.1242/jcs.114595 
42. Chan YW, West SC (2014) Spatial control of the GEN1 Holliday junction resolvase ensures genome stability. Nat Commun 5:4844. https://doi.org/10.1038/ncomms5844

43. Garner E, Kim Y, Lach FP, et al (2013) Human GEN1 and the SLX4-associated nucleases MUS81 and SLX1 are essential for the resolution of replication-induced Holliday junctions. Cell Rep 5:207-215. https://doi.org/10.1016/j.celrep.2013.08.041

44. Terasawa M, Shinohara A, Shinohara M (2014) Canonical non-homologous end joining in mitosis induces genome instability and is suppressed by M-phase-specific phosphorylation of XRCC4. PLoS Genet 10:e1004563. https://doi.org/10.1371/journal.pgen.1004563

45. Kubara PM, Kernéis-Golsteyn S, Studény A, et al (2012) Human cells enter mitosis with damaged DNA after treatment with pharmacological concentrations of genotoxic agents. Biochem J 446:373381. https://doi.org/10.1042/BJ20120385

46. Kalsbeek D, Golsteyn RM (2017) G2/M-Phase Checkpoint Adaptation and Micronuclei Formation as Mechanisms That Contribute to Genomic Instability in Human Cells. Int J Mol Sci 18:. https://doi.org/10.3390/ijms18112344

47. Yang $\mathrm{H}$, Wang $\mathrm{H}$, Ren J, et al (2017) cGAS is essential for cellular senescence. Proc Natl Acad Sci USA 114:E4612-E4620. https://doi.org/10.1073/pnas.1705499114

48. Jiang $H$, Xue X, Panda $S$, et al (2019) Chromatin-bound cGAS is an inhibitor of DNA repair and hence accelerates genome destabilization and cell death. EMBO J 38:e102718. https://doi.org/10.15252/embj.2019102718

49. Zierhut C, Yamaguchi N, Paredes M, et al (2019) The Cytoplasmic DNA Sensor cGAS Promotes Mitotic Cell Death. Cell 178:302-315.e23. https://doi.org/10.1016/j.cell.2019.05.035

50. Lin W-W, Karin M (2007) A cytokine-mediated link between innate immunity, inflammation, and cancer. J Clin Invest 117:1175-1183. https://doi.org/10.1172/JCl31537

51. He Z, Gharaibeh RZ, Newsome RC, et al (2019) Campylobacter jejuni promotes colorectal tumorigenesis through the action of cytolethal distending toxin. Gut 68:289-300. https://doi.org/10.1136/gutjnl-2018-317200

52. Ng KW, Marshall EA, Bell JC, Lam WL (2018) cGAS-STING and Cancer: Dichotomous Roles in Tumor Immunity and Development. Trends Immunol 39:44-54. https://doi.org/10.1016/j.it.2017.07.013

53. Huber W, Carey VJ, Gentleman R, et al (2015) Orchestrating high-throughput genomic analysis with Bioconductor. Nat Methods 12:115-121. https://doi.org/10.1038/nmeth.3252

54. Bolstad BM, Irizarry RA, Astrand M, Speed TP (2003) A comparison of normalization methods for high density oligonucleotide array data based on variance and bias. Bioinformatics 19:185-193. https://doi.org/10.1093/bioinformatics/19.2.185

55. Ritchie ME, Phipson B, Wu D, et al (2015) limma powers differential expression analyses for RNAsequencing and microarray studies. Nucleic Acids Res 43:e47. https://doi.org/10.1093/nar/gkv007

56. Pons BJ, Bezine E, Hanique M, et al (2019) Cell transfection of purified cytolethal distending toxin B subunits allows comparing their nuclease activity while plasmid degradation assay does not. PLoS ONE 14:e0214313. https://doi.org/10.1371/journal.pone.0214313 


\section{References}

1. Jinadasa RN, Bloom SE, Weiss RS, Duhamel GE (2011) Cytolethal distending toxin: a conserved bacterial genotoxin that blocks cell cycle progression, leading to apoptosis of a broad range of mammalian cell lineages. Microbiology 157:1851-1875. https://doi.org/10.1099/mic.0.049536-0

2. World Health Organization (2015) WHO estimates of the global burden of foodborne diseases: foodborne disease burden epidemiology reference group 2007-2015, World Health Organization

3. Ahmed HJ, Svensson LA, Cope LD et al (2001) Prevalence of cdtABC genes encoding cytolethal distending toxin among Haemophilus ducreyi and Actinobacillus actinomycetemcomitans strains. J Med Microbiol 50:860-864. https://doi.org/10.1099/0022-1317-50-10-860

4. Redondo N, Carroll A, McNamara E (2019) Molecular characterization of Campylobacter causing human clinical infection using whole-genome sequencing: Virulence, antimicrobial resistance and phylogeny in Ireland. PLoS One 14:e0219088. https://doi.org/10.1371/journal.pone.0219088

5. Barakat AMA, El-Razik KAA, Elfadaly HA et al (2020) Prevalence, molecular detection, and virulence gene profiles of Campylobacter species in humans and foods of animal origin. Vet World 13:14301438. https://doi.org/10.14202/vetworld.2020.1430-1438

6. Wysok B, Wojtacka J, Hänninen M-L, Kivistö R (2020) Antimicrobial Resistance and VirulenceAssociated Markers in Campylobacter Strains From Diarrheic and Non-diarrheic Humans in Poland. Front Microbiol 11:1799. https://doi.org/10.3389/fmicb.2020.01799

7. Klem F, Wadhwa A, Prokop LJ et al (2017) Prevalence, Risk Factors, and Outcomes of Irritable Bowel Syndrome After Infectious Enteritis: A Systematic Review and Meta-analysis. Gastroenterology 152:1042-1054.e1. https://doi.org/10.1053/j.gastro.2016.12.039

8. Rezaie A, Park SC, Morales W et al (2017) Assessment of Anti-vinculin and Anti-cytolethal Distending Toxin B Antibodies in Subtypes of Irritable Bowel Syndrome. Dig Dis Sci 62:1480-1485. https://doi.org/10.1007/s10620-017-4585-z

9. Okuda J, Fukumoto M, Takeda Y, Nishibuchi M (1997) Examination of diarrheagenicity of cytolethal distending toxin: suckling mouse response to the products of the cdtABC genes of Shigella dysenteriae. Infect Immun 65:428-433. https://doi.org/10.1128/IAI.65.2.428-433.1997

10. Pratt JS, Sachen KL, Wood HD et al (2006) Modulation of host immune responses by the cytolethal distending toxin of Helicobacter hepaticus. Infect Immun 74:4496-4504. https://doi.org/10.1128/IAl.00503-06

11. Fox JG, Rogers AB, Whary MT et al (2004) Gastroenteritis in NF-kappaB-deficient mice is produced with wild-type Camplyobacter jejuni but not with $\mathrm{C}$. jejuni lacking cytolethal distending toxin despite persistent colonization with both strains. Infect Immun 72:1116-1125.

https://doi.org/10.1128/iai.72.2.1116-1125.2004

12. Ge Z, Rogers AB, Feng $Y$ et al (2007) Bacterial cytolethal distending toxin promotes the development of dysplasia in a model of microbially induced hepatocarcinogenesis. Cell Microbiol 9:2070-2080. https://doi.org/10.1111/j.1462-5822.2007.00939.x 
13. Martin OCB, Frisan T (2020) Bacterial Genotoxin-Induced DNA Damage and Modulation of the Host Immune Microenvironment. Toxins (Basel) 12:. https://doi.org/10.3390/toxins12020063

14. Akifusa S, Poole S, Lewthwaite J et al (2001) Recombinant Actinobacillus actinomycetemcomitans cytolethal distending toxin proteins are required to interact to inhibit human cell cycle progression and to stimulate human leukocyte cytokine synthesis. Infect Immun 69:5925-5930. https://doi.org/10.1128/iai.69.9.5925-5930.2001

15. Shenker BJ, Walker LP, Zekavat A et al (2014) Blockade of the PI-3K signalling pathway by the Aggregatibacter actinomycetemcomitans cytolethal distending toxin induces macrophages to synthesize and secrete pro-inflammatory cytokines. Cell Microbiol 16:1391-1404. https://doi.org/10.1111/cmi.12299

16. Belibasakis GN, Johansson A, Wang Y et al (2005) Cytokine responses of human gingival fibroblasts to Actinobacillus actinomycetemcomitans cytolethal distending toxin. Cytokine 30:56-63. https://doi.org/10.1016/j.cyto.2004.11.008

17. Zheng J, Meng J, Zhao S et al (2008) Campylobacter-induced interleukin-8 secretion in polarized human intestinal epithelial cells requires Campylobacter-secreted cytolethal distending toxin- and Toll-like receptor-mediated activation of NF-kappaB. Infect Immun 76:4498-4508. https://doi.org/10.1128/IAI.01317-07

18. Nesić D, Hsu Y, Stebbins CE (2004) Assembly and function of a bacterial genotoxin. Nature 429:429433. https://doi.org/10.1038/nature02532

19. Song J, Gao X, Galán JE (2013) Structure and function of the Salmonella Typhi chimaeric A(2)B(5) typhoid toxin. Nature 499:350-354. https://doi.org/10.1038/nature12377

20. Pons BJ, Vignard J, Mirey G (2019) Cytolethal Distending Toxin Subunit B: A Review of StructureFunction Relationship. Toxins (Basel) 11:. https://doi.org/10.3390/toxins11100595

21. Elwell CA, Dreyfus LA (2000) DNase I homologous residues in CdtB are critical for cytolethal distending toxin-mediated cell cycle arrest. Mol Microbiol 37:952-963. https://doi.org/10.1046/j.1365-2958.2000.02070.x

22. Bezine E, Vignard J, Mirey G (2014) The cytolethal distending toxin effects on Mammalian cells: a DNA damage perspective. Cells 3:592-615. https://doi.org/10.3390/cells3020592

23. Cortes-Bratti X, Karlsson C, Lagergård T et al (2001) The Haemophilus ducreyi cytolethal distending toxin induces cell cycle arrest and apoptosis via the DNA damage checkpoint pathways. J Biol Chem 276:5296-5302. https://doi.org/10.1074/jbc.M008527200

24. Frisan T, Cortes-Bratti X, Chaves-Olarte E et al (2003) The Haemophilus ducreyi cytolethal distending toxin induces DNA double-strand breaks and promotes ATM-dependent activation of RhoA. Cell Microbiol 5:695-707. https://doi.org/10.1046/j.1462-5822.2003.00311.x

25. Fahrer $\mathrm{J}$, Huelsenbeck $\mathrm{J}$, Jaurich $\mathrm{H}$ et al (2014) Cytolethal distending toxin (CDT) is a radiomimetic agent and induces persistent levels of DNA double-strand breaks in human fibroblasts. DNA Repair 18:31-43. https://doi.org/10.1016/j.dnarep.2014.03.002 
26. Blazkova H, Krejcikova K, Moudry P et al (2010) Bacterial intoxication evokes cellular senescence with persistent DNA damage and cytokine signalling. J Cell Mol Med 14:357-367. https://doi.org/10.1111/j.1582-4934.2009.00862.x

27. Rodier F, Coppé J-P, Patil CK et al (2009) Persistent DNA damage signalling triggers senescenceassociated inflammatory cytokine secretion. Nat Cell Biol 11:973-979. https://doi.org/10.1038/ncb1909

28. Harding SM, Benci JL, Irianto J et al (2017) Mitotic progression following DNA damage enables pattern recognition within micronuclei. Nature 548:466-470. https://doi.org/10.1038/nature23470

29. Mackenzie KJ, Carroll P, Martin C-A et al (2017) CGAS surveillance of micronuclei links genome instability to innate immunity. Nature 548:461-465. https://doi.org/10.1038/nature23449

30. Li T, Chen ZJ (2018) The cGAS-cGAMP-STING pathway connects DNA damage to inflammation, senescence, and cancer. J Exp Med 215:1287-1299. https://doi.org/10.1084/jem.20180139

31. Fedor Y, Vignard J, Nicolau-Travers M-L et al (2013) From single-strand breaks to double-strand breaks during S-phase: a new mode of action of the Escherichia coli Cytolethal Distending Toxin. Cell Microbiol 15:1-15. https://doi.org/10.1111/cmi.12028

32. Bezine E, Malaisé Y, Loeuillet A et al (2016) Cell resistance to the Cytolethal Distending Toxin involves an association of DNA repair mechanisms. Sci Rep 6:36022.

https://doi.org/10.1038/srep36022

33. Jullien D, Vignard J, Fedor $Y$ et al (2016) Chromatibody, a novel non-invasive molecular tool to explore and manipulate chromatin in living cells. J Cell Sci 129:2673-2683. https://doi.org/10.1242/jcs.183103

34. Ichijima Y, Sakasai R, Okita N et al (2005) Phosphorylation of histone H2AX at M phase in human cells without DNA damage response. Biochem Biophys Res Commun 336:807-812. https://doi.org/10.1016/j.bbrc.2005.08.164

35. Graillot V, Dormoy I, Dupuy J et al (2016) Genotoxicity of Cytolethal Distending Toxin (CDT) on Isogenic Human Colorectal Cell Lines: Potential Promoting Effects for Colorectal Carcinogenesis. Front Cell Infect Microbiol 6:34. https://doi.org/10.3389/fcimb.2016.00034

36. Johnson WM, Lior H (1988) A new heat-labile cytolethal distending toxin (CLDT) produced by Escherichia coli isolates from clinical material. Microb Pathog 4:103-113. https://doi.org/10.1016/0882-4010(88)90052-6

37. Orthwein A, Fradet-Turcotte A, Noordermeer SM et al (2014) Mitosis inhibits DNA double-strand break repair to guard against telomere fusions. Science 344:189-193. https://doi.org/10.1126/science.1248024

38. Blackford AN, Stucki M (2020) How Cells Respond to DNA Breaks in Mitosis. Trends Biochem Sci 45:321-331. https://doi.org/10.1016/j.tibs.2019.12.010

39. Araujo AR, Gelens L, Sheriff RSM, Santos SDM (2016) Positive Feedback Keeps Duration of Mitosis Temporally Insulated from Upstream Cell-Cycle Events. Mol Cell 64:362-375. https://doi.org/10.1016/j.molcel.2016.09.018 
40. Weitzman MD, Weitzman JB (2014) What's the damage? The impact of pathogens on pathways that maintain host genome integrity. Cell Host Microbe 15:283-294. https://doi.org/10.1016/j.chom.2014.02.010

41. Rodrigue A, Coulombe $Y$, Jacquet $K$ et al (2013) The RAD51 paralogs ensure cellular protection against mitotic defects and aneuploidy. J Cell Sci 126:348-359. https://doi.org/10.1242/jcs.114595

42. Chan YW, West SC (2014) Spatial control of the GEN1 Holliday junction resolvase ensures genome stability. Nat Commun 5:4844. https://doi.org/10.1038/ncomms5844

43. Garner E, Kim Y, Lach FP et al (2013) Human GEN1 and the SLX4-associated nucleases MUS81 and SLX1 are essential for the resolution of replication-induced Holliday junctions. Cell Rep 5:207-215. https://doi.org/10.1016/j.celrep.2013.08.041

44. Terasawa M, Shinohara A, Shinohara M (2014) Canonical non-homologous end joining in mitosis induces genome instability and is suppressed by M-phase-specific phosphorylation of XRCC4. PLoS Genet 10:e1004563. https://doi.org/10.1371/journal.pgen.1004563

45. Kubara PM, Kernéis-Golsteyn S, Studény A et al (2012) Human cells enter mitosis with damaged DNA after treatment with pharmacological concentrations of genotoxic agents. Biochem J 446:373-381. https://doi.org/10.1042/BJ20120385

46. Kalsbeek D, Golsteyn RM (2017) G2/M-Phase Checkpoint Adaptation and Micronuclei Formation as Mechanisms That Contribute to Genomic Instability in Human Cells. Int J Mol Sci 18:. https://doi.org/10.3390/ijms18112344

47. Yang $H$, Wang $H$, Ren $J$ et al (2017) cGAS is essential for cellular senescence. Proc Natl Acad Sci USA 114:E4612-E4620. https://doi.org/10.1073/pnas.1705499114

48. Jiang $H$, Xue X, Panda $S$ et al (2019) Chromatin-bound cGAS is an inhibitor of DNA repair and hence accelerates genome destabilization and cell death. EMBO J 38:e102718. https://doi.org/10.15252/embj.2019102718

49. Zierhut C, Yamaguchi N, Paredes M et al (2019) The Cytoplasmic DNA Sensor cGAS Promotes Mitotic Cell Death. Cell 178:302-315.e23. https://doi.org/10.1016/j.cell.2019.05.035

50. Lin W-W, Karin M (2007) A cytokine-mediated link between innate immunity, inflammation, and cancer. J Clin Invest 117:1175-1183. https://doi.org/10.1172/JCl31537

51. He Z, Gharaibeh RZ, Newsome RC et al (2019) Campylobacter jejuni promotes colorectal tumorigenesis through the action of cytolethal distending toxin. Gut 68:289-300. https://doi.org/10.1136/gutjnl-2018-317200

52. Ng KW, Marshall EA, Bell JC, Lam WL (2018) cGAS-STING and Cancer: Dichotomous Roles in Tumor Immunity and Development. Trends Immunol 39:44-54. https://doi.org/10.1016/j.it.2017.07.013

53. Huber W, Carey VJ, Gentleman R et al (2015) Orchestrating high-throughput genomic analysis with Bioconductor. Nat Methods 12:115-121. https://doi.org/10.1038/nmeth.3252

54. Bolstad BM, Irizarry RA, Astrand M, Speed TP (2003) A comparison of normalization methods for high density oligonucleotide array data based on variance and bias. Bioinformatics 19:185-193. https://doi.org/10.1093/bioinformatics/19.2.185 
55. Ritchie ME, Phipson B, Wu D et al (2015) limma powers differential expression analyses for RNAsequencing and microarray studies. Nucleic Acids Res 43:e47. https://doi.org/10.1093/nar/gkv007

56. Pons BJ, Bezine E, Hanique M et al (2019) Cell transfection of purified cytolethal distending toxin B subunits allows comparing their nuclease activity while plasmid degradation assay does not. PLoS ONE 14:e0214313. https://doi.org/10.1371/journal.pone.0214313

\section{Figures}

A
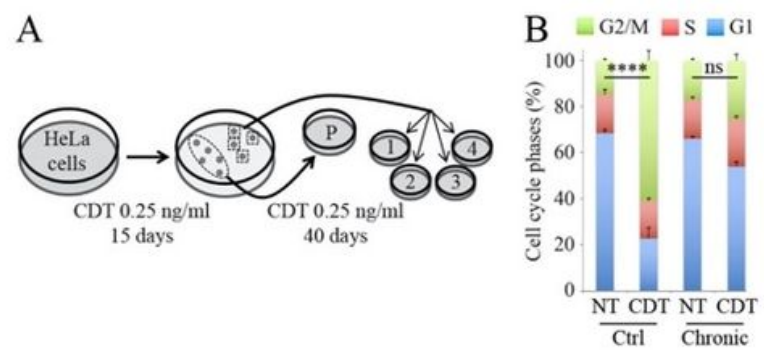

G

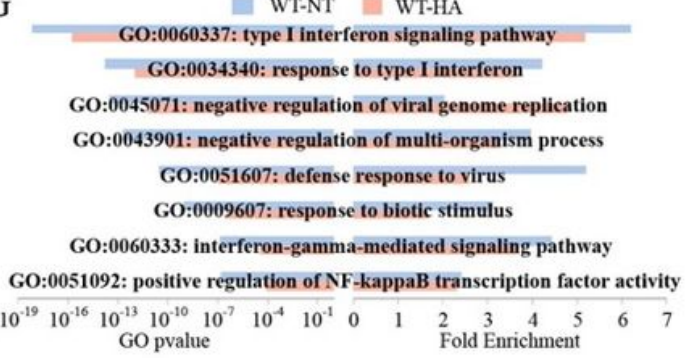

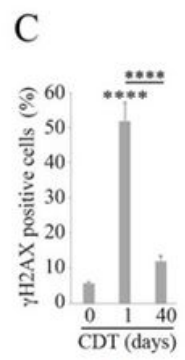
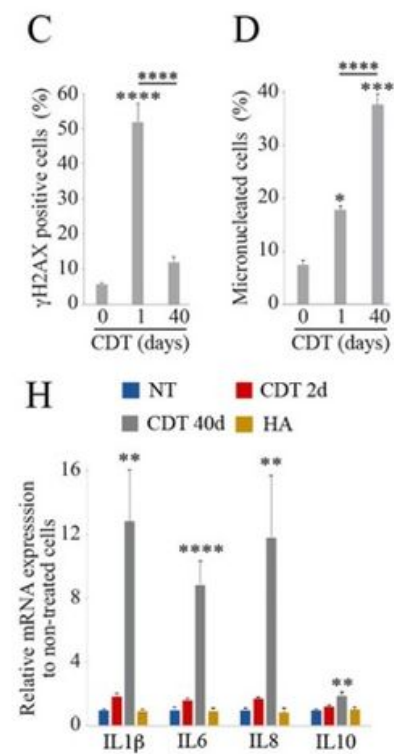

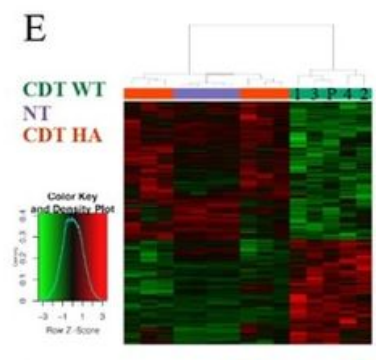

F

I

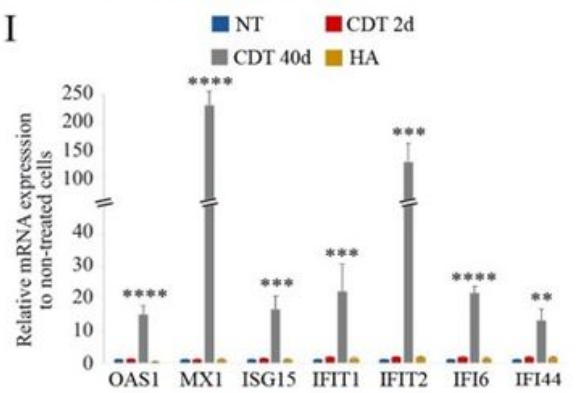

\section{Figure 1}

Chronic exposure to CDT induces a type I IFN proinflammatory response. (A) Schematic of the selection procedure of HeLa cells chronically exposed to CDT. Individual clones (1-4) and a multiclonal cell population (P) were obtained. (B) Cells from A were exposed to CDT $2.5 \mathrm{ng} / \mathrm{ml}$ for $24 \mathrm{~h}$ and subjected to cell cycle analyzes by flow-cytometry. Data represent the mean \pm SEM $\left(N^{3} 3\right)$. Statistics (only G2/M) were calculated by two-way ANOVA followed by Sidak's multiple comparison test. ( $C$ and D) HeLa cells were exposed for $24 \mathrm{~h}$ or 40 days as in A and the frequency of gH2AX positive cells (C) or cells with micronuclei (D) was quantified. Data represent the mean \pm SEM (N33). Statistics were calculated by oneway ANOVA followed by Tukey's multiple comparison test. (E-G) HeLa cells non-treated (NT) or from A exposed to wild-type CDT (CDT WT) or the catalytic mutant H153A (CDT HA) were compared after microarray gene expression analysis. Heatmap (E) shows the significantly altered genes expression (FDR $<0.05$ and fold change $>1$ ), and Venn diagram (F) shows overlap between the most upregulated genes (FDR $<0.05$ and fold change $>3$ ). Graphs $(G)$ represent the 8 most significant upregulated biological processes sorted according to adjusted $p$ value obtained from a hypergeometric enrichment test on Gene Ontology (GO) processes. (I and J) HeLa cells non-treated (NT) or exposed to CDT WT $0.25 \mathrm{ng} / \mathrm{ml}$ for 2 days, and cells from A exposed to CDT WT or HA were collected and the mRNA level of indicated genes 
was analyzed by RT-qPCR. Data represent the mean \pm SEM $\left(\mathrm{N}^{3} 3\right)$. Statistics were calculated by one-way ANOVA followed by Dunnet's multiple comparison test.

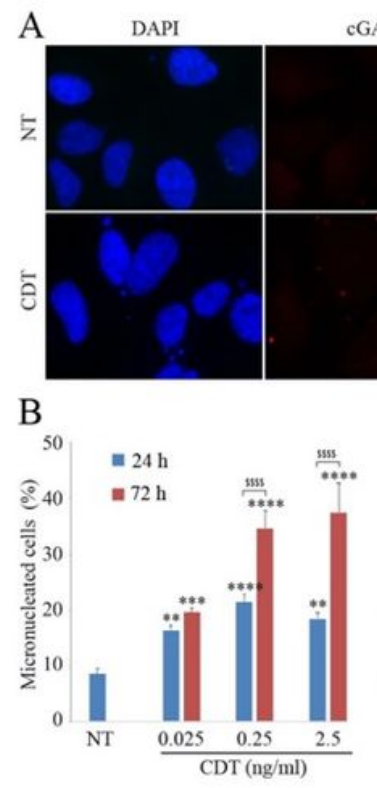

cGAS

$\gamma \mathrm{H} 2 \mathrm{AX}$

Merge

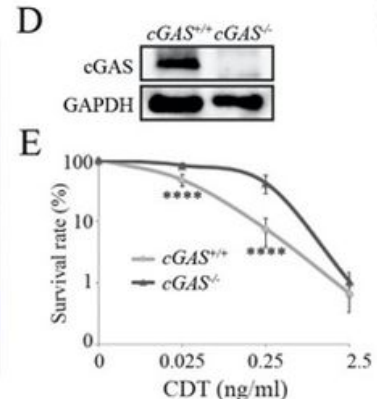

$\mathrm{C}$
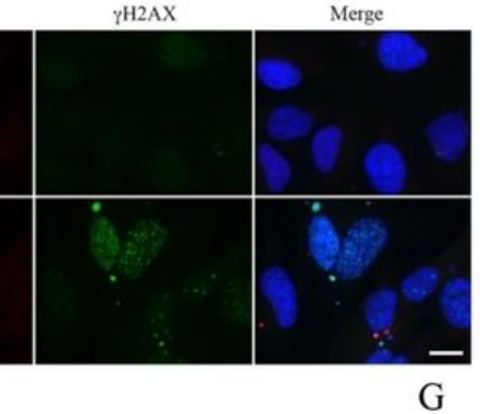

G

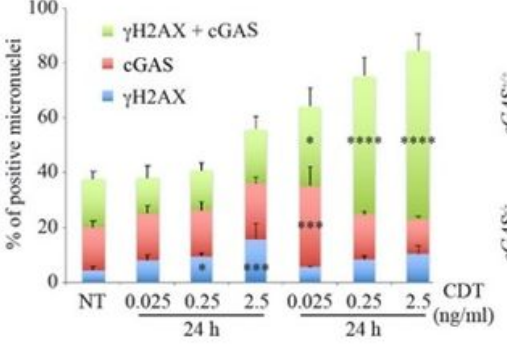

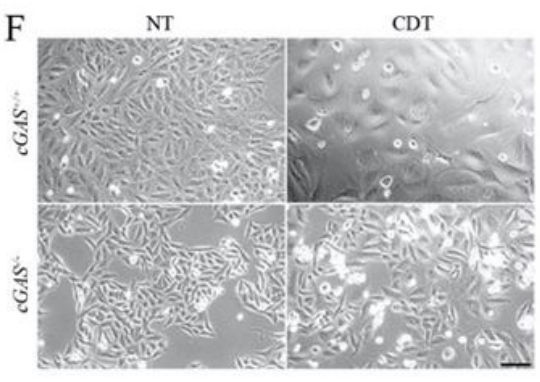

$\mathrm{H}$

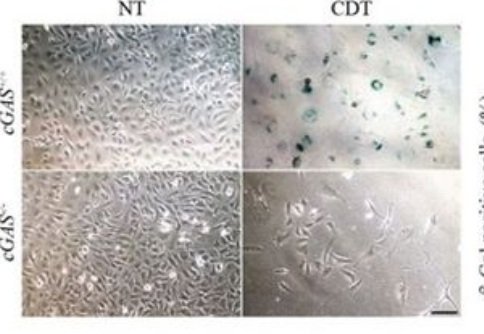

I

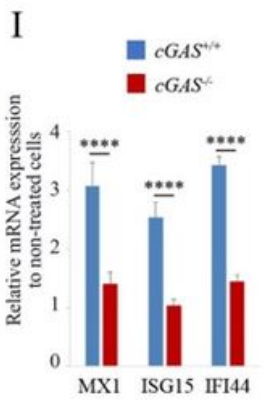

Figure 2

CDT-induced micronuclei promote a cGAS-dependent proinflammatory response. (A-C) HeLa cells were exposed for 24 or $72 \mathrm{~h}$ to CDT and analyzed by immunofluorescence microscopy with antibodies against cGAS and $\mathrm{yH} 2 \mathrm{AX}$. Representative images at $72 \mathrm{~h}(\mathrm{~A})$ and quantification of micronucleated cells $(\mathrm{B})$ and cGAS and/or $y H 2 A X$ positive cells are shown. Scale bar $=20 \mu \mathrm{m}$. Data represent the mean \pm SEM (N³). Statistics were calculated by two-way ANOVA followed by Dunnett's multiple comparison test. (D) Soluble fractions of cGAS+/+ and cGAS-/- HeLa cells were analyzed by Western blotting. (E) cGAS+/+ and cGAS-/- HeLa cells were exposed to CDT and subjected to colony formation assay. (F-H) cGAS+/+ and cGAS-/- HeLa cells were exposed to CDT $2.5 \mathrm{ng} / \mathrm{ml}$ for $90 \mathrm{~h}$ and analyzed by light microscopy without (F) or with $\beta-G a l$ staining ( $G$ and $H)$. Scale bars $=100 \mu \mathrm{m}$. Quantification of $\beta-G a l$ positive cells is shown $(H)$. (I) cGAS+/+ and cGAS-/- HeLa cells were exposed to CDT $0.25 \mathrm{ng} / \mathrm{ml}$ for 10 days and the mRNA level of MX1, ISG15 and IFI44 was analyzed by RT-qPCR. (E, H and I) Data represent the mean \pm SEM (N³). Statistics were calculated by two-way ANOVA followed by Sidak's multiple comparison test 

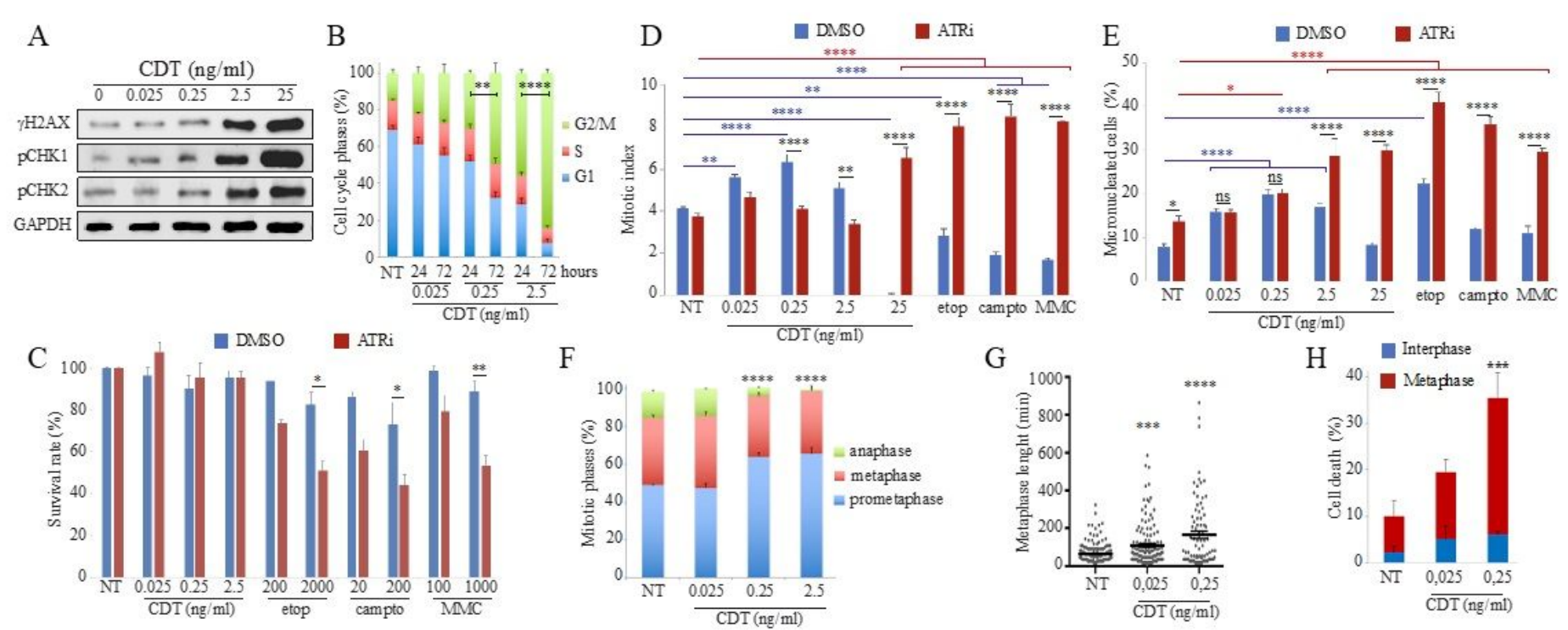

\section{Figure 3}

CDT-exposed cells do not block at G2 during the first cell cycle and show mitotic defects. (A) HeLa cells were exposed for $24 \mathrm{~h}$ to CDT and soluble fractions were analyzed by Western blot with the indicated antibodies. (B) HeLa cells were exposed for 24 or $72 \mathrm{~h}$ to CDT and subjected to cell cycle analyzes by flow-cytometry. (C) HeLa cells were exposed for $24 \mathrm{~h}$ to CDT, etop, campto or MMC with or without ATRi and subjected to CellTiter-Glo viability assay. (D and E) HeLa cells were exposed for $24 \mathrm{~h}$ to CDT, etop 200 $\mathrm{nM}$, campto $20 \mathrm{nM}$ or MMC $100 \mathrm{nM}$ with or without ATRi. Mitotic index (D) and the frequency of cells with $M N(E)$ were quantified. (B-E) Data represent the mean \pm SEM (N³). Statistics (only G2/M for B) were calculated by two-way ANOVA followed by Sidak's multiple comparison test. (F) HeLa cells were exposed for $24 \mathrm{~h}$ to CDT and the proportion of prometaphase, metaphase or anaphase were quantified. Data represent the mean \pm SEM $\left(N^{3} 3\right)$. Statistics (anaphase only) were calculated by one-way ANOVA followed by Dunnett's multiple comparison test. ( $\mathrm{G}$ and $\mathrm{H}$ ) HeLa cells stably expressing the chromatibody-GFP (Jullien et al., 2016) were exposed to CDT or etop $200 \mathrm{nM}$ and analyzed by time-laps fluorescence imaging. Graphs show the average time duration of metaphase to anaphase transition \pm SEM of one representative experiment $(N=3)(G)$, and the mean of cell death at interphase or metaphase $\pm S E M(N=3)$ $(\mathrm{H})$. Statistics were calculated by one-way $(\mathrm{G})$ or two-way $(\mathrm{H})$ ANOVA followed by Dunnett's multiple comparison test. 
A

pH3 $\mathrm{S} 10$ positive

$\gamma \mathrm{H} 2 \mathrm{AX}+\mathrm{pH} 3 \mathrm{~S} 10$ positive

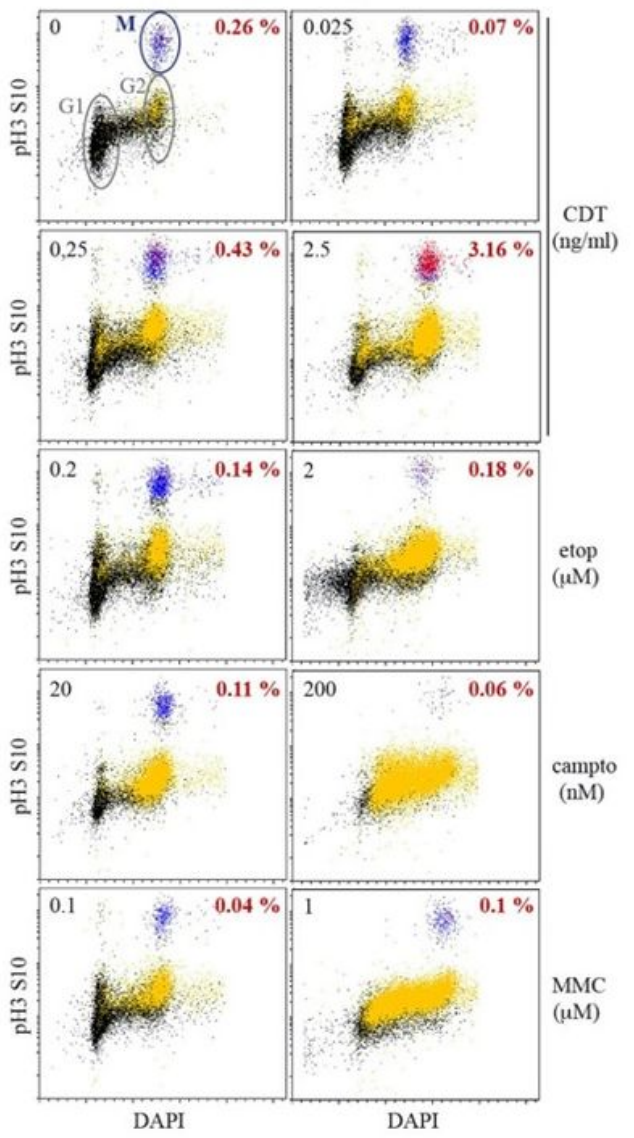

B

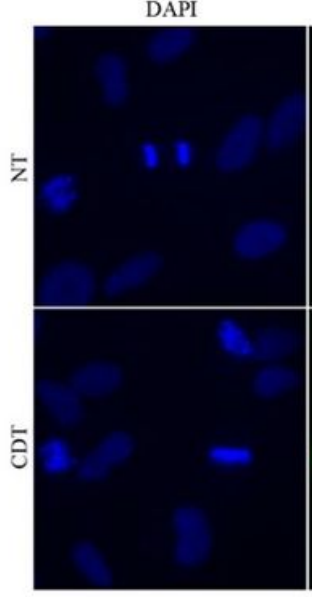

C

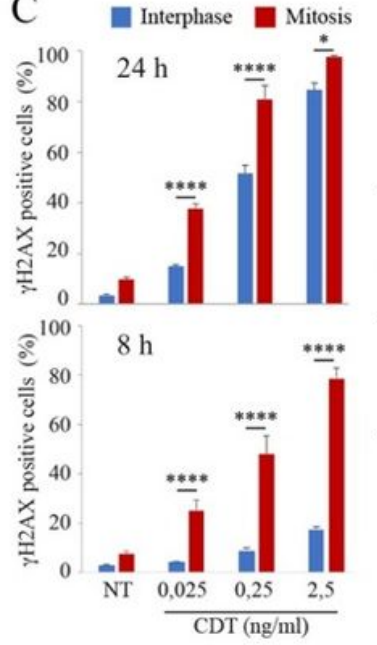

$\gamma \mathrm{H} 2 \mathrm{AX}$

pH3 S10

Merge

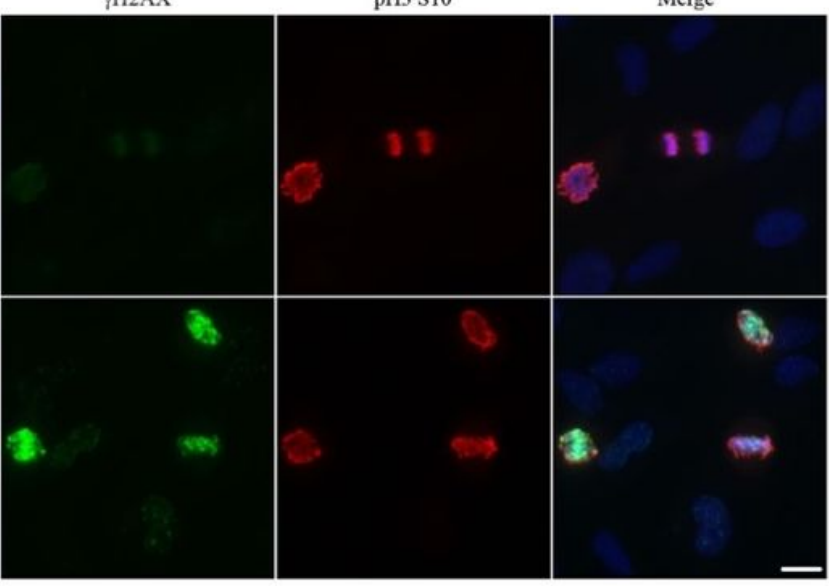

D

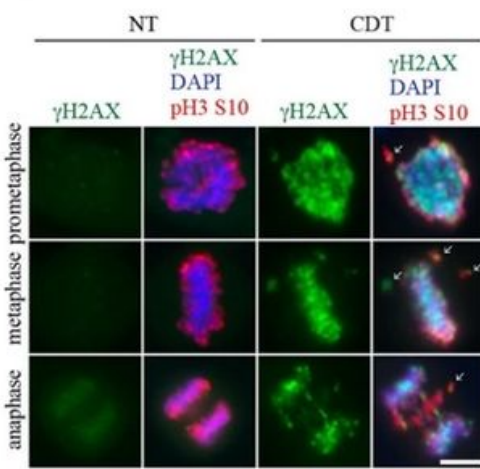

E

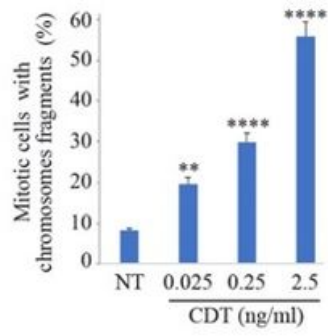

\section{Figure 4}

CDT-exposed cells accumulate DNA damage at mitosis. (A) HeLa cells were exposed for $24 \mathrm{~h}$ to CDT, etop, campto or MMC, immunostained with antibodies directed against $\mathrm{gH} 2 \mathrm{AX}$ and $\mathrm{pH} 3$ and subjected to cell cycle analyzes by flow-cytometry. Graphs of the cell cycle profiles from one representative experiment $(\mathrm{N}=2)$ show unstained cells (black), or with gH2AX (yellow), $\mathrm{pH}$ ( $\mathrm{M}$ for mitosis, blue) or both staining (red). Percentage in red indicate the proportion of $\mathrm{gH} 2 \mathrm{AX}+\mathrm{pH} 3$ positive cells. ( $\mathrm{B}$ and $\mathrm{C}$ ) HeLa cells were exposed to CDT for $24 \mathrm{~h}$ or $8 \mathrm{~h}$, and analyzed by immunofluorescence microscopy with antibodies directed against $\mathrm{gH} 2 \mathrm{AX}$ and $\mathrm{pH}$. Representative images (B) and quantification (C) are shown. Scale bar $=20 \mu \mathrm{m}$. Data represent the mean \pm SEM (N33). Statistics were calculated by two-way ANOVA followed by Sidak's multiple comparison test. (D and E) HeLa cells were exposed for $24 \mathrm{~h}$ to CDT, etop $200 \mathrm{nM}$, campto 20 nM or MMC 100 nM and analyzed by immunofluorescence microscopy with antibodies directed against $\mathrm{gH} 2 \mathrm{AX}$ and $\mathrm{pH}$. Representative images of mitotic cells in prometaphase, metaphase or anaphase (D) and quantification of chromosome fragments in prometaphase and metaphase (E) are shown. Scale bar $=10 \mu \mathrm{m}$. White arrows indicate chromosome fragments. Data represent the mean \pm SEM (N=3). Statistics were calculated by one-way ANOVA followed by Dunnett's multiple comparison test. 
A

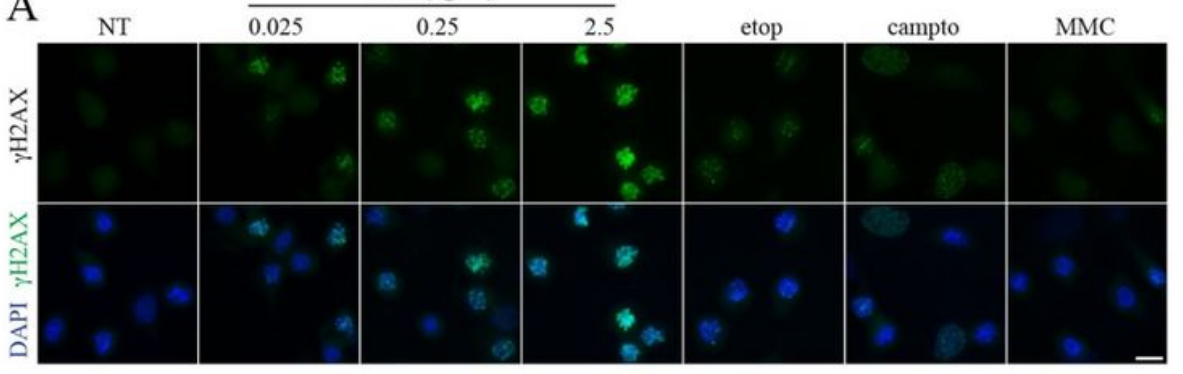

B

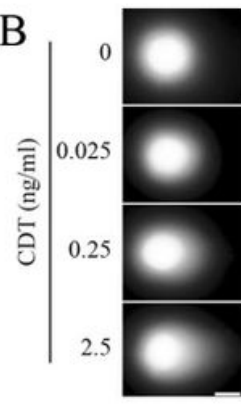

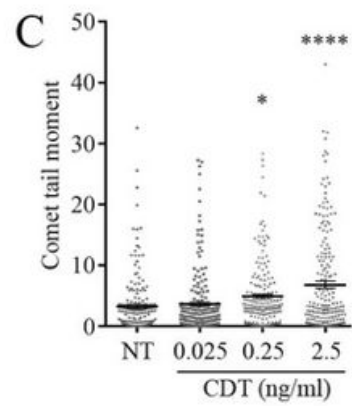

\section{Figure 5}

CDT induces DNA damage during mitosis. (A) HeLa cells were exposed for $22 \mathrm{~h}$ to nocodazole, with CDT, etop $200 \mathrm{nM}$, campto $20 \mathrm{nM}$ or MMC $100 \mathrm{nM}$ during the last $6 \mathrm{~h}$ and analyzed by immunofluorescence microscopy with an antibody directed against gH2AX. Images of one representative experiment are shown ( $N=4)$. Scale bar $=20 \mu \mathrm{m}$. (B and $C$ ) HeLa cells were synchronized in mitosis, exposed for $12 \mathrm{~h}$ to CDT and analyzed by neutral comet assay. Representative images (B) and quantification of individual cells tail moment $(C)$ are shown. Scale bar $=20 \mu \mathrm{m}$. Data represent the mean \pm SEM $(N=3)$. Statistics were calculated by two-way (B) or one-way (D) ANOVA followed by Dunnett's multiple comparison test.
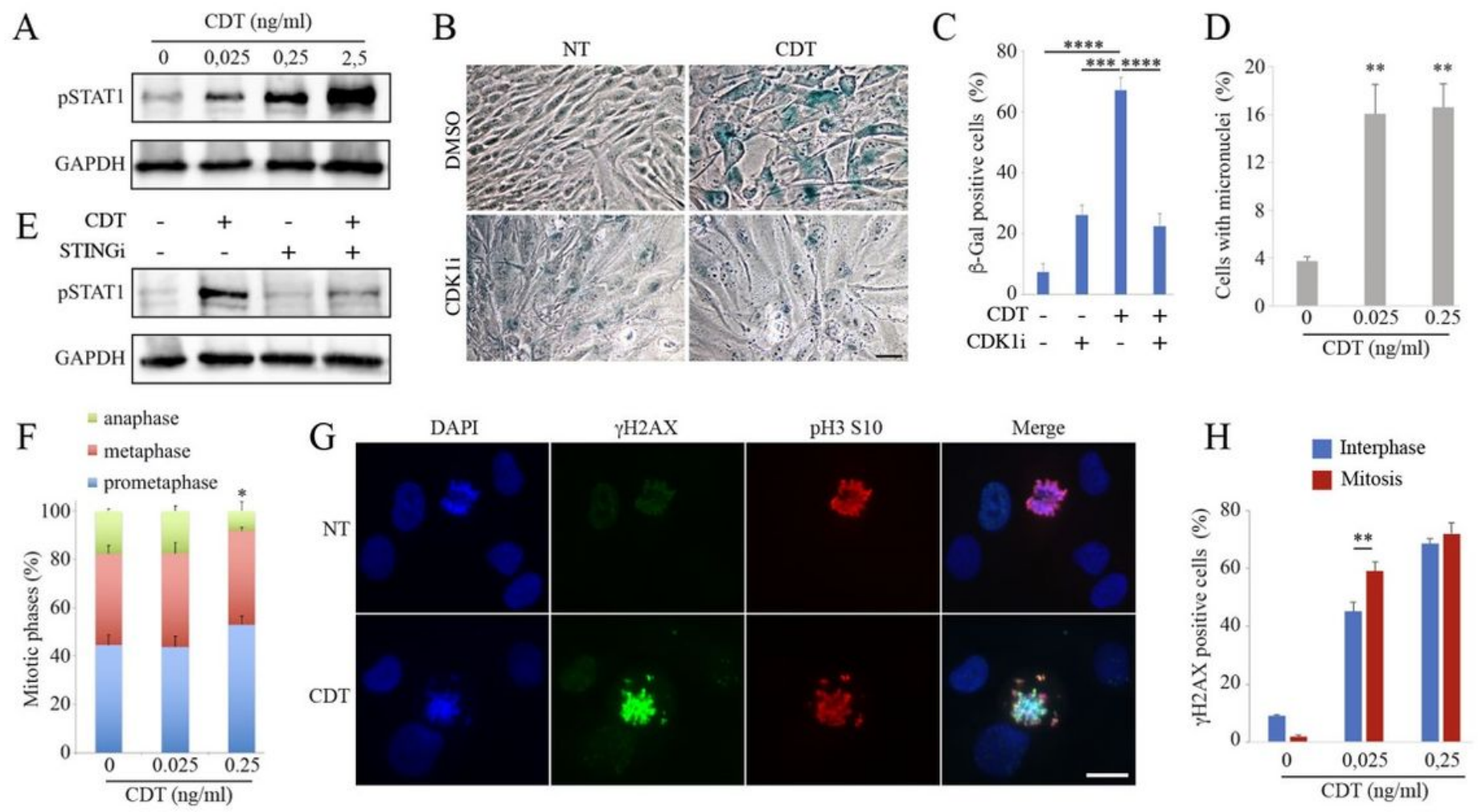

Figure 6

Normal HCEC cells treated with CDT display proinflammatory responses and mitotic defects. (A) HCEC cells were exposed for $96 \mathrm{~h}$ to CDT and soluble fractions were analyzed by Western blotting with the indicated antibodies. (B and C) HCEC cells were exposed to CDT $0.25 \mathrm{ng} / \mathrm{ml}$ for $96 \mathrm{~h}$ with or without 
CDK1 $\mathrm{i}$ and analyzed by light microscopy with $\beta$-Gal staining. Scale bars $=50 \mu \mathrm{m}$. Representative images (B) and quantification of $\beta$-Gal positive cells (C) are shown. Data represent the mean $\pm \operatorname{SEM}(\mathrm{N}=3)$. Statistics were calculated by one-way ANOVA followed by Tukey's multiple comparison test. (D) HCECs cells were exposed for $24 \mathrm{~h}$ to CDT and analyzed by immunofluorescence microscopy with an antibody directed against $\mathrm{pH}$. The proportion of micronucleated cells was quantified. (E) HCEC cells were exposed for $96 \mathrm{~h}$ to CDT with or without STINGi and soluble fractions were analyzed by Western blotting with the indicated antibodies. (F) HCEC cells were treated as in D and the proportion of prometaphase, metaphase and anaphase was quantified. ( $\mathrm{G}$ and $\mathrm{H}$ ) HCECs cells were exposed for $8 \mathrm{~h}$ to CDT and analyzed by immunofluorescence microscopy with antibodies directed against $\mathrm{gH} 2 \mathrm{AX}$ and $\mathrm{pH} 3$. Representative images $(G)$ and quantification of $g H 2 A X$ positive cells $(H)$ are shown. (D, $F$ and $H)$ Data represent the mean \pm SEM (N33). Statistics (only anaphase for $F$ ) were calculated by one-way ( $D$ and $F$ ) or two-way $(H)$ ANOVA followed by Dunnett's ( $D$ and $F$ ) or Sidak's $(H)$ multiple comparison test.

\section{Supplementary Files}

This is a list of supplementary files associated with this preprint. Click to download.

- SupplementalMaterials.pdf

- SupplementaryFigures.pdf 